\title{
Global and regional evaluation of over-land spectral aerosol optical depth retrievals from SeaWiFS
}

\author{
A. M. Sayer ${ }^{1,2}$, N. C. Hsu' ${ }^{2}$, C. Bettenhausen ${ }^{2,3}$, M.-J. Jeong ${ }^{4}$, B. N. Holben ${ }^{2}$, and J. Zhang ${ }^{5}$ \\ ${ }^{1}$ Goddard Earth Sciences Technology And Research (GESTAR), Universities Space Research Association (USRA), \\ Columbia, Maryland, USA \\ ${ }^{2}$ NASA Goddard Space Flight Center, Greenbelt, Maryland, USA \\ ${ }^{3}$ Science Systems Applications Inc., Lanham, Maryland, USA \\ ${ }^{4}$ Department of Atmospheric and Environmental Sciences, Gangneung-Wonju National University, Gangneung, \\ Gangwon-do, Korea \\ ${ }^{5}$ Department of Atmospheric Sciences, University of North Dakota, Grand Forks, North Dakota, USA
}

Correspondence to: A. M. Sayer (andrew.sayer@nasa.gov)

Received: 27 February 2012 - Published in Atmos. Meas. Tech. Discuss.: 14 March 2012

Revised: 25 June 2012 - Accepted: 26 June 2012 - Published: 25 July 2012

\begin{abstract}
This study evaluates a new spectral aerosol optical depth (AOD) dataset derived from Sea-viewing Wide Field-of-view Sensor (SeaWiFS) measurements over land. First, the data are validated against Aerosol Robotic Network (AERONET) direct-sun AOD measurements and found to compare well on a global basis. If only data with the highest quality flag are used, the correlation is 0.86 and $72 \%$ of matchups fall within an expected absolute uncertainty of $0.05+20 \%$ (for the wavelength of $550 \mathrm{~nm}$ ). The quality is similar at other wavelengths and stable over the 13-yr (1997-2010) mission length. Performance tends to be better over vegetated, low-lying terrain with typical AOD of 0.3 or less, such as found over much of North America and Eurasia. Performance tends to be poorer for low-AOD conditions near backscattering geometries, where SeaWiFS overestimates AOD, or optically-thick cases of absorbing aerosol, where SeaWiFS tends to underestimate AOD. Second, the SeaWiFS data are compared with midvisible AOD derived from the Moderate Resolution Imaging Spectrometer (MODIS) and Multiangle Imaging Spectroradiometer (MISR). All instruments show similar spatial and seasonal distributions of AOD, although there are regional and seasonal offsets between them. At locations where AERONET data are available, these offsets are largely consistent with the known validation characteristics of each dataset. With the results of this study in mind, the SeaWiFS over-land AOD record is suitable for quantitative scientific use.
\end{abstract}

\section{Introduction}

The remote sensing of aerosol optical depth (AOD) from passive satellite radiance measurements over land is generally more complicated than over ocean. Reasons for this include a brighter and more heterogeneous surface reflectance, diversity in aerosol microphysical properties, difficulties in cloud identification and, particularly near strong aerosol sources, heterogeneity of the aerosol itself. The limited information content of current and previous instruments of this type (Hasekamp and Landgraf, 2007) has led to the development of many different AOD retrieval algorithms, utilising the strengths and mitigating the weaknesses of each sensor (e.g., Kokhanovsky and de Leeuw, 2009).

Retrieved AOD from these datasets is typically evaluated using ground-based estimates of AOD, from measurements of the extinction of direct solar radiation using sunphotometers (e.g., Ichoku et al., 2002; Kahn et al., 2010; Levy et al., 2010; Sayer et al., 2012). The methodology adopted in this work draws from these studies. This evaluation is an important component in establishing the reliability of the satellite data for scientific use, such as in studies of air quality (Gupta and Christopher, 2008; Hoff and Christopher, 2009), radiative forcing (Chylek et al., 2003; Bellouin et al., 2005), trend detection (Zhang and Reid, 2010; Yoon et al., 2011), or visibility and aerosol forecasts (Zhang et al., 2008, 2011). The difficulty of accurate AOD retrieval over 
land has so far limited some of these applications (e.g., Li et al., 2009).

At the time of writing, the longest single-sensor record suitable for determination of column AOD over land and ocean surfaces is the Sea-viewing Wide Field-of-view Sensor (SeaWiFS), which was in operation between September 1997 and December 2010, with a small number of temporary outages. The main focus of the SeaWiFS mission was determination of ocean colour parameters (McClain et al., 2004). Due to the small contribution of the ocean to the reflected solar radiance at top-of-atmosphere (TOA), this requires a highly accurate and stable calibration, which was maintained over the mission (Eplee Jr. et al., 2011; of order $1-3 \%$ absolute calibration accuracy and temporal stability around $0.3 \%$ ). The long time series and quality of calibration make SeaWiFS a good candidate sensor for the creation of an AOD dataset. With an equatorial crossing time around noon (albeit drifting into the early afternoon in its final few years), SeaWiFS's sampling time was in between other satellite platforms which carry instruments suitable for AOD retrieval (e.g., Terra, ERS-2, or Envisat in the mid-morning and the A-Train in the early afternoon).

For these reasons, the Deep Blue Utilization of SeaWiFS Through the Data and Information Services Center (DUSTDISC) project has created such an AOD record from SeaWiFS. The current version (v003) is freely available from http: //disc.gsfc.nasa.gov/dust/ along with supporting documentation for users. Both Level 2 (individual orbit) and Level 3 (daily/monthly gridded composite) products are available. Further information about the dataset, including details and validation of the algorithm used over water, is provided by Sayer et al. (2012). The over-land AOD retrieval is based on the "Deep Blue" algorithm (Hsu et al., 2004, 2006), which is part of the operational MODerate Resolution Imaging Spectroradiometer (MODIS) processing. The aim of this paper is to evaluate the over-land AOD dataset through validation of Level 2 AOD retrievals with Aerosol Robotic Network (AERONET) data (Holben et al., 1998) and comparison with other satellite AOD datasets derived from MODIS and Multiangle Imaging Spectroradiometer (MISR) measurements on a Level 3 basis.

Section 2 describes the satellite and ground-based data used in the study, and Sect. 3 presents some general results concerning the dependence of comparison statistics on factors such as geometry and data quality flags. Next, Sect. 4 discusses individual regions in more detail. Finally, Sect. 5 summarises the main results of the study.

\section{Datasets and methodology used}

\subsection{SeaWiFS}

The over-land SeaWiFS aerosol dataset provides retrieved $\mathrm{AOD}$ at the commonly-used reference wavelength of $550 \mathrm{~nm}$, at the SeaWiFS bands centred near $490 \mathrm{~nm}$ and $670 \mathrm{~nm}$ and, over some surface types, the band centred near $412 \mathrm{~nm}$. The primary quantity of interest is the AOD at $550 \mathrm{~nm}, \tau_{550}$, where the subscripted number indicates the wavelength in $\mathrm{nm}$. Unless otherwise specified, references to AOD imply $\tau_{550}$.

The algorithm is an updated version of that used in the original application to MODIS and retains the same basic principles (see Hsu et al., 2004, 2006 for a description) as the sensors share the bands used for AOD retrieval (although the SeaWiFS equivalent of the MODIS $488 \mathrm{~nm}$ channel is centred near $470 \mathrm{~nm}$ ). The updated algorithm as applied to SeaWiFS and the forthcoming MODIS Collection 6 will be detailed further in a future publication, but some general points are presented in brief here.

Initially, the Deep Blue algorithm is applied to cloudcleared SeaWiFS reflectances to retrieve AOD at full instrumental resolution, which is approximately $4.5 \mathrm{~km} \times 4.5 \mathrm{~km}$ at the sub-satellite point. These individual-pixel retrievals are then averaged to $3 \times 3$ pixel (i.e., $13.5 \mathrm{~km} \times 13.5 \mathrm{~km}$ ) "cell" resolution, which is reported in the Level 2 (orbit) product. Statistics about the AOD within a cell (e.g., number of cloudfree pixels, variability of retrieved AOD within a cell) are used to define an associated quality assurance (QA) flag with a value between 1 and 3 , with 3 indicating the most confidence in the retrieval and 1 the least; over land, only QA $=3$ retrievals are used to create the Level 3 products. The rationale behind the QA decisions is that cells containing few retrievals, or highly variable retrieved AOD, are less likely to be reliable, due to factors such as residual cloud contamination or strong inhomogeneity in the region.

There are two main developments between the original MODIS Deep Blue algorithm and this "second generation" SeaWiFS version. Firstly, the algorithm is also applied over vegetated land surfaces, and not just bright arid surfaces. The principle remains the same over vegetated surfaces: a prescribed database of surface reflectance and sets of aerosol models are used to retrieve spectral AOD by matching observed TOA reflectances with those stored in precalculated lookup tables of radiative transfer results for different surface, atmospheric and geometric conditions.

The second main development is this surface reflectance database itself. For MODIS, a set of four databases (one per season) were used, based upon the Lambertian-equivalent reflectivity (LER) observed for a given location through the mission. The idea behind the creation of such a database is that, once observations affected by clouds, cloud shadows and inland water are discarded, the clearest days would likely correspond to the lowest LER, and as such that could provide an estimate of the surface reflectance. A similar, but more sophisticated, approach is applied for SeaWiFS: the LER database is further stratified by viewing geometry, to provide a method of accounting for surface bidirectional reflectance distribution function (BRDF) effects. This database is supplemented in some regions by using AERONET AOD 
observations from selected sites as an additional constraint to derive empirical BRDFs based on polynomials in scattering angle. The calculation is performed separately for each wavelength. The surface database is available upon request to the authors. These aspects will be described further in the aforementioned forthcoming publication.

The comparisons presented in this paper can be divided into two types, described in the succeeding sections.

\subsection{AERONET validation}

Comparison of spectral AOD with AERONET data on a Level 2 basis helps to establish the reliability of the SeaWiFS data in many different aerosol/surface regimes. The AERONET record provides spectral AOD in several bands between the ultraviolet (UV; $340 \mathrm{~nm}$ ) and shortwave infrared (swIR; $1640 \mathrm{~nm}$ ) with an uncertainty of order $0.01-0.02$; the larger uncertainties are found in the UV (Holben et al., 1998; Eck et al., 1999). However, Chew et al. (2011) suggested that over regions with cirrus cloud contamination, the uncertainty of AERONET AOD may be doubled. The exact band configuration depends on the specific instrument. The validation protocol is as adopted in Sayer et al. (2012), and previouslycited studies. AERONET provides a point measurement with a temporal resolution around $15 \mathrm{~min}$, while SeaWiFS provides a single-time measurement with a spatial footprint of $13.5 \mathrm{~km} \times 13.5 \mathrm{~km}$ (at the sub-satellite point). Additionally, AERONET samples the direct atmospheric path between the Sun and the site, while SeaWiFS measures light which has travelled this path and then been reflected into the viewing direction. To mitigate these sampling differences, the former dataset is averaged in time, and the latter in space. A valid matchup is defined when there is at least one AERONET measurement within $30 \mathrm{~min}$ of the satellite overpass, and at least one SeaWiFS retrieval in a $25 \mathrm{~km}$ radius of the AERONET site.

Only cloud-screened and quality-assured Level 2.0 AERONET data (Smirnov et al., 2000) are used. A total of 183 AERONET sites are used, each providing at least 10 matchups when the SeaWiFS data are restricted to the highest quality flag $(\mathrm{QA}=3)$. Note that only 109 of these sites include a comparison of AOD at $412 \mathrm{~nm}$ due to absence of AERONET and/or SeaWiFS data in the relevant bands.

As the SeaWiFS and AERONET bands do not match, in this study the AERONET AODs are interpolated spectrally to the relevant SeaWiFS wavelength using the Ångström power law, $\alpha=d \ln \tau / d \ln \lambda$, where the Ångström exponent $\alpha$ used for this interpolation is provided in the standard AERONET data product, and the interpolation uses the spectrally-closest $\tau$ and $\alpha$ to the desired SeaWiFS wavelength. The spectral variability of AOD is generally smooth, so the error introduced by this interpolation is negligible. AERONET data are denoted with a subscripted A, i.e., $\tau_{\mathrm{A}}$. The SeaWiFS dataset provides $\alpha$ evaluated between $490 \mathrm{~nm}$ and $670 \mathrm{~nm}$ (except over arid surfaces where AOD at $412 \mathrm{~nm}$ is retrieved, in which case $412 \mathrm{~nm}$ and $490 \mathrm{~nm}$ are used); this is also compared with the closest AERONET $\alpha(440 \mathrm{~nm}-675 \mathrm{~nm})$, and unless specified otherwise, further references to $\alpha$ indicate this combination.

\subsection{Multi-satellite comparison}

The second type of comparison involves satellite-derived midvisible AOD (550 nm for SeaWiFS and MODIS, $558 \mathrm{~nm}$ for MISR). In the interests of brevity, and because $550 \mathrm{~nm}$ is a common reference, only this one quantity is considered. As sampling and aggregation choices can have significant effects on such comparisons (Levy et al., 2009; Sayer et al., 2010), to minimise the effects of spatio-temporal mismatch between the data, daily Level 3 data are used. The purpose of this is to show how the SeaWiFS data compare to the widely-used MODIS and MISR products on a global and regional scale. Multiple publications have already addressed the comparison of over-land MODIS and MISR data products with AERONET and each other (Liu and Mishchenko, 2008; Mishchenko et al., 2009, 2010; Kahn et al., 2009, 2010, 2011; Levy et al., 2010; Hyer et al., 2011; Shi et al., 2011), so this will only be discussed where relevant in the context of SeaWiFS. The local overpass times of the satellites vary between late morning and early afternoon; Smirnov et al. (2002) observed that variability of AOD between these times is of order $10 \%$ of the daily mean AOD or less for most aerosol types, and so is unlikely to be a major contributing factor to observed offsets in many regions (although aerosol transport may contribute to scatter).

The comparison uses the standard Level 3 daily products for the period 2006-2010. For MISR, this is the version 22 dataset (Martonchik et al., 2009; Kahn et al., 2010). For MODIS, two sets of products are considered. Firstly, the MODIS Collection 5.1 standard product, "Deep Blue" over arid surfaces (Hsu et al., 2004, 2006) and "Dark Target" over vegetated surfaces (Levy et al., 2007). Secondly, the "data-assimilation (DA) quality" MODIS AOD (hereafter DA-MODIS), which is an attempt to create a filtered and bias-corrected version of the MODIS Collection 5.1 "Dark Target" data (Hyer et al., 2011). The MODIS sensors aboard the Terra and Aqua satellites are considered separately.

The comparisons with MODIS are at $1^{\circ}$ horizontal resolution, while that with MISR is at $0.5^{\circ}$, corresponding to the different resolutions of their standard products. Because the mutual overlap of all datasets on a given day is low, colocations are performed between SeaWiFS and each other dataset on an individual basis. To be considered for the comparison, grid cells in the daily products are only considered where both datasets contain at least 10 retrievals for the $1^{\circ}$ comparisons, or 3 for the $0.5^{\circ}$ comparisons, these thresholds being roughly equivalent relative to the grid size. 


\subsection{Definition of regions}

Both sets of analyses consider over-land data globally, and also stratified into one of nine different regions, as shown in Fig. 1. The choice of regions is somewhat arbitrary and is not intended to follow geopolitical boundaries, but allows a fairly coarse examination of the retrieval under different atmospheric and surface conditions. For example, a generally low AOD and dense vegetation are found over much of eastern North America or Eurasia, but an arid surface and periodic dust storms are found in northern Africa and the Middle East. Nine regions, corresponding roughly with those often used in regional analyses of aerosol properties, were chosen as a compromise between isolating individual aerosol/surface regimes and retaining sufficient data volume in each to present a meaningful analysis.

\section{Global comparison with AERONET data}

\subsection{Effect of QA}

Considering data from all AERONET sites together, and restricting SeaWiFS data to $\mathrm{QA}=3$ only, leads to joint histograms of SeaWiFS and AERONET AOD or Ångström exponent as shown in Fig. 2, revealing a high level of agreement in spectral AOD. The Ångström exponent compares poorly, but if only cases of moderate or high $\mathrm{AOD}\left(\tau_{\mathrm{A}, 550}>0.3\right)$ are considered, the correlation improves. This is expected as in low-AOD conditions small uncertainties on $\tau$ can propagate to large uncertainties on $\alpha$ (Wagner and Silva, 2008), and similar behaviour is generally found in other satellite datasets (e.g., Levy et al., 2010). Some artifacts are visible in the distributions of $\alpha$; namely, that $\alpha$ is forced to 1 in SeaWiFS if $\tau_{550}<0.1$ (due to a lack of information), and a lower limit of $\alpha \geq-0.4$ is set in most regions.

An important concept (Kahn et al., 2010; Levy et al., 2010; Sayer et al., 2012, and others) is the notion of expected error (EE); namely, what is the confidence envelope which describes the uncertainty on the SeaWiFS AOD? This can be estimated from the comparisons with AERONET, assuming that the AERONET data represent an unbiased and comparatively low-error measure of the true AOD. The goal is to define some function such that the absolute difference between SeaWiFS and AERONET falls within this EE for one standard deviation $(\sim 68 \%)$ of the colocations, and two standard deviations ( $\sim 95 \%)$ within twice this EE. Hence, the EE represents the one-sigma uncertainty on the SeaWiFS data, taking AERONET as the truth. The error ratio (ER) for an individual matchup is then defined as the difference between SeaWiFS and AERONET AOD, divided by the EE.

The established over-land EE for MODIS Dark Target and MISR midvisible AODs are $0.05+0.15 \tau_{\mathrm{A}, 550}$ and the greater of 0.05 or $0.2 \tau_{\mathrm{A}, 550}$, respectively. An AODdependent component is linked to uncertainties associated
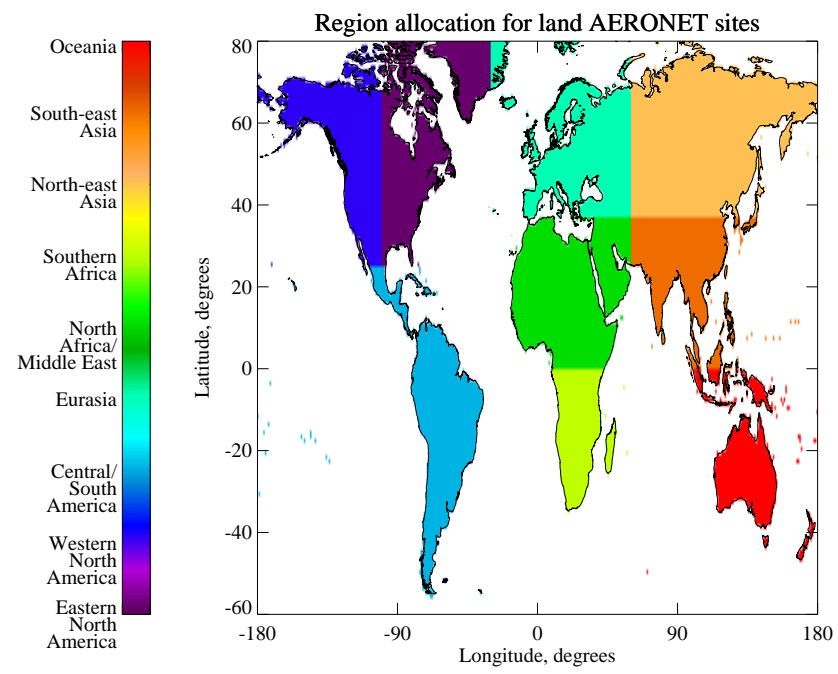

Fig. 1. Geographical bounds of land regions used in this study for comparison of SeaWiFS AOD with other datasets.

with aerosol microphysical model assumptions, while an AOD-independent component is linked to factors such as uncertainties in surface reflectance modelling. Simulations and experience with SeaWiFS data suggest that the EE should be larger, as SeaWiFS is lacking in spectral resolution compared to MODIS, angular resolution compared to MISR, and spatial resolution compared to both.

Assessment of the set of matchups with $\mathrm{QA}=3$ suggests that an appropriate set of spectral EE are $0.05+0.25 \tau_{\mathrm{A}, 412}$, $0.05+0.20 \tau_{\mathrm{A}, 490}, 0.05+0.20 \tau_{\mathrm{A}, 550}$, and $0.05+0.15 \tau_{\mathrm{A}, 670}$, which are met by over $68 \%$ of the points (Table 1). Dependent on wavelength, 90-95\% fall within twice the EE, indicating there are slightly more outliers than would be expected if these expressions of EE were true Gaussian measures of the retrieval uncertainty. Because the AERONET uncertainty is much smaller, it can be neglected for the estimation of EE. No EE is estimated for $\alpha$; as Fig. 2 shows, it is qualitatively clustered with the AERONET data for $\tau_{\mathrm{A}, 550}>0.3$, although is not recommended for use for lower AOD. Additionally, for low aerosol loading, the uncertainty on AERONET AOD can itself be significant in calculating $\alpha$ (Wagner and Silva, 2008).

If the requirement for $\mathrm{QA}=3$ retrievals is relaxed, the number of comparisons increases, although the correlation and fraction of comparisons within the EE decreases (Table 1). This suggests that the SeaWiFS quality flags do provide information about the quality of the retrieval. The true decrease in quality with decreasing quality flag may be more extreme than noted here, as a primary reason for assignment of a low QA flag is suspicion of cloudcontamination. By definition the points in the AERONET comparison have passed cloud-screening for both the SeaWiFS and AERONET datasets, so the frequency of cloudcontamination in SeaWiFS retrievals is likely higher in the 
Table 1. Statistics of validation of spectral AOD with AERONET data, for different thresholds on the minimum SeaWiFS QA value permitted, and both area-averaged and direct colocations. $R$ is Pearson's linear correlation coefficient.

\begin{tabular}{|c|c|c|c|c|c|c|c|c|c|c|c|c|}
\hline \multirow[t]{2}{*}{$\begin{array}{l}\text { Minimum } \\
\text { QA }\end{array}$} & \multicolumn{4}{|c|}{$\begin{array}{l}\text { Number of matchups } \\
\text { Wavelength, nm }\end{array}$} & \multicolumn{4}{|c|}{$\begin{array}{c}R \\
\text { Wavelength, nm } \\
\end{array}$} & \multicolumn{4}{|c|}{$\begin{array}{l}\text { Fraction within EE } \\
\text { Wavelength, nm }\end{array}$} \\
\hline & 412 & 490 & 550 & 670 & 412 & 490 & 550 & 670 & 412 & 490 & 550 & 670 \\
\hline \multicolumn{13}{|c|}{$25 \mathrm{~km}, 30 \mathrm{~min}$ spatiotemporal average } \\
\hline 1 & 27555 & 67191 & 67202 & 67075 & 0.80 & 0.81 & 0.81 & 0.79 & 0.64 & 0.62 & 0.64 & 0.61 \\
\hline 2 & 22942 & 56508 & 56512 & 56512 & 0.83 & 0.84 & 0.83 & 0.80 & 0.68 & 0.67 & 0.69 & 0.66 \\
\hline 3 & 12823 & 34722 & 34727 & 34728 & 0.83 & 0.86 & 0.86 & 0.84 & 0.73 & 0.71 & 0.72 & 0.69 \\
\hline \multicolumn{13}{|c|}{ Direct spatial matchup, 15 min temporal average } \\
\hline 1 & 16908 & 44669 & 44659 & 44503 & 0.80 & 0.79 & 0.79 & 0.75 & 0.64 & 0.62 & 0.64 & 0.61 \\
\hline 2 & 12629 & 32436 & 32426 & 32427 & 0.83 & 0.85 & 0.84 & 0.81 & 0.69 & 0.68 & 0.69 & 0.66 \\
\hline 3 & 6224 & 17886 & 17879 & 17881 & 0.83 & 0.87 & 0.86 & 0.85 & 0.72 & 0.71 & 0.72 & 0.69 \\
\hline
\end{tabular}
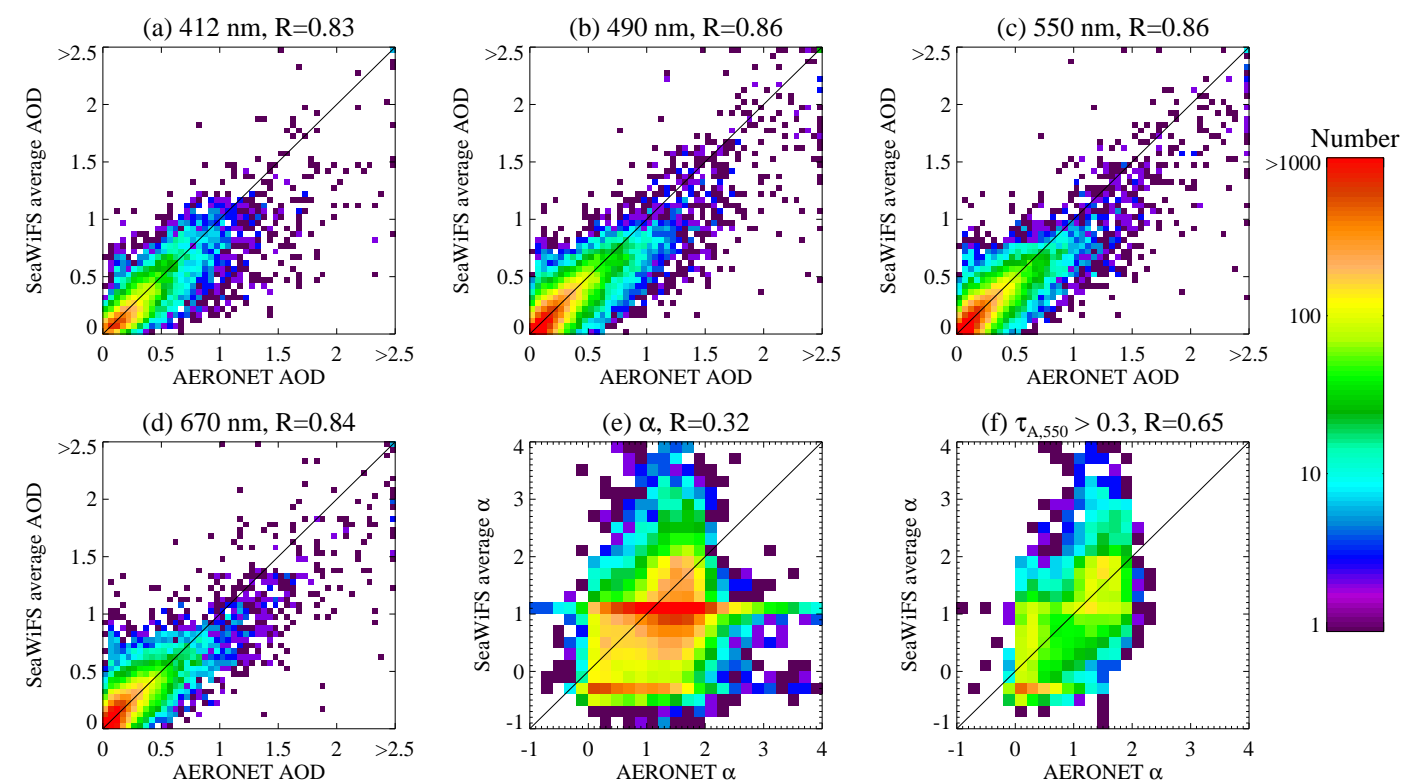

Fig. 2. Scatter density plots between SeaWiFS and AERONET spectral AOD, for (a) $412 \mathrm{~nm}$, (b) $490 \mathrm{~nm}$, (c) $550 \mathrm{~nm}$, (d) $670 \mathrm{~nm}$, (e) Ångström exponent (for all points), (f) Ångström exponent (for $\tau_{\mathrm{A}, 550} \geq 0.3$ ). Only points where $\mathrm{QA}=3$ are included. Correlation coefficients are shown above each panel.

whole dataset than the subset with valid AERONET comparisons. For these reasons, only $\mathrm{QA}=3$ data are recommended for general use, although QA $=2$ may also be useful if for a specific application a user possesses additional information such as auxiliary cloud masks. Only QA $=3$ data were used for the generation of available over-land SeaWiFS level 3 data products.

Finally, it is relevant whether or not restriction to $\mathrm{QA}=3$ data introduces a sampling bias into the underlying distribution of AOD. Figure 3 shows histograms of the AERONET AOD at $550 \mathrm{~nm}$, for the nine regions in Fig. 1, for the colocations obtained by each different SeaWiFS QA threshold. Each region generally approximates a lognormal distribution (also noted by O'Neill et al., 2000 for individual AERONET sites), although peaks and widths differ. The Central/South America region has a longer positive tail, which is likely due to seasonal biomass burning aerosol observed at several of the sites (notably Abracos Hill, Alta Floresta and Rio Branco). The histograms of AOD are very similar for all QA thresholds, which suggests that restricting to only $\mathrm{QA}=3 \mathrm{SeaWiFS}$ data does not cause a sampling bias in the "true" distribution of AOD. The region with the least similarity between the $\mathrm{QA}=3$ distribution and others is north-eastern Asia. The majority of the points in this region are from urban areas in China, or the Gobi Desert. In these cases it appears that restriction to $\mathrm{QA}=3$ reduces the 

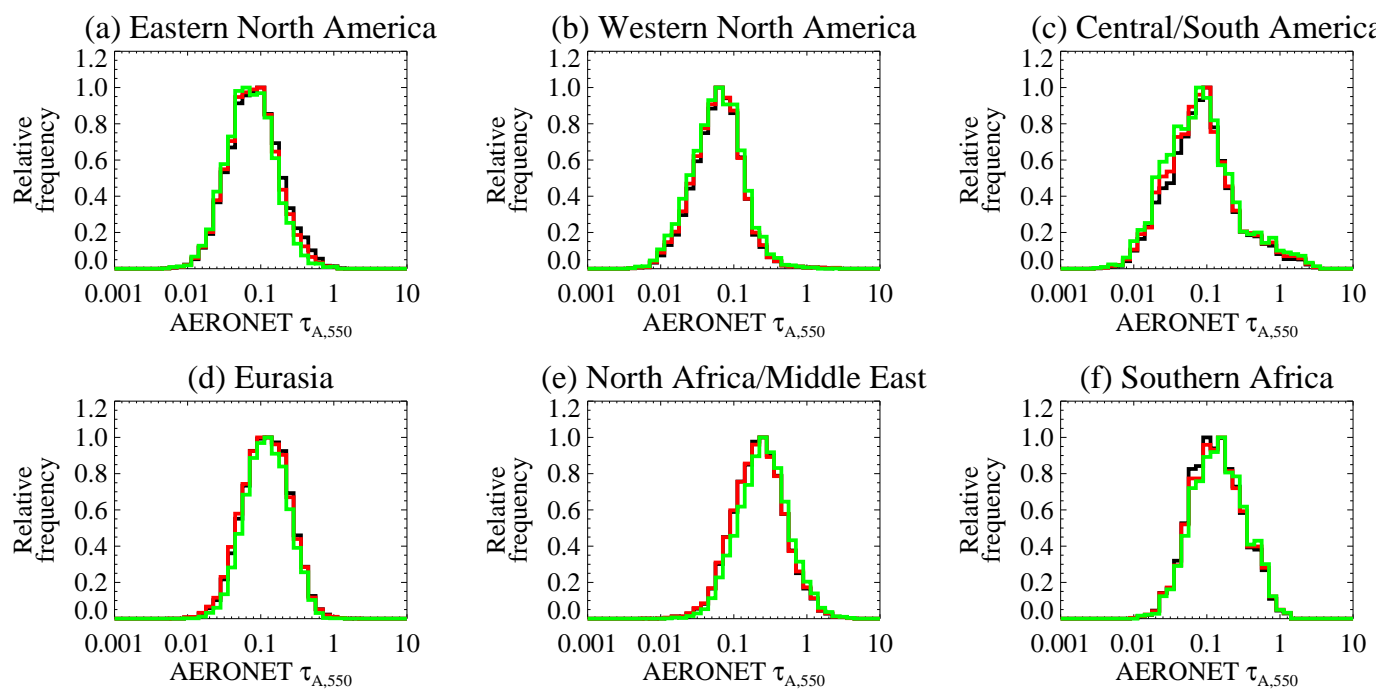

(e) North Africa/Middle East
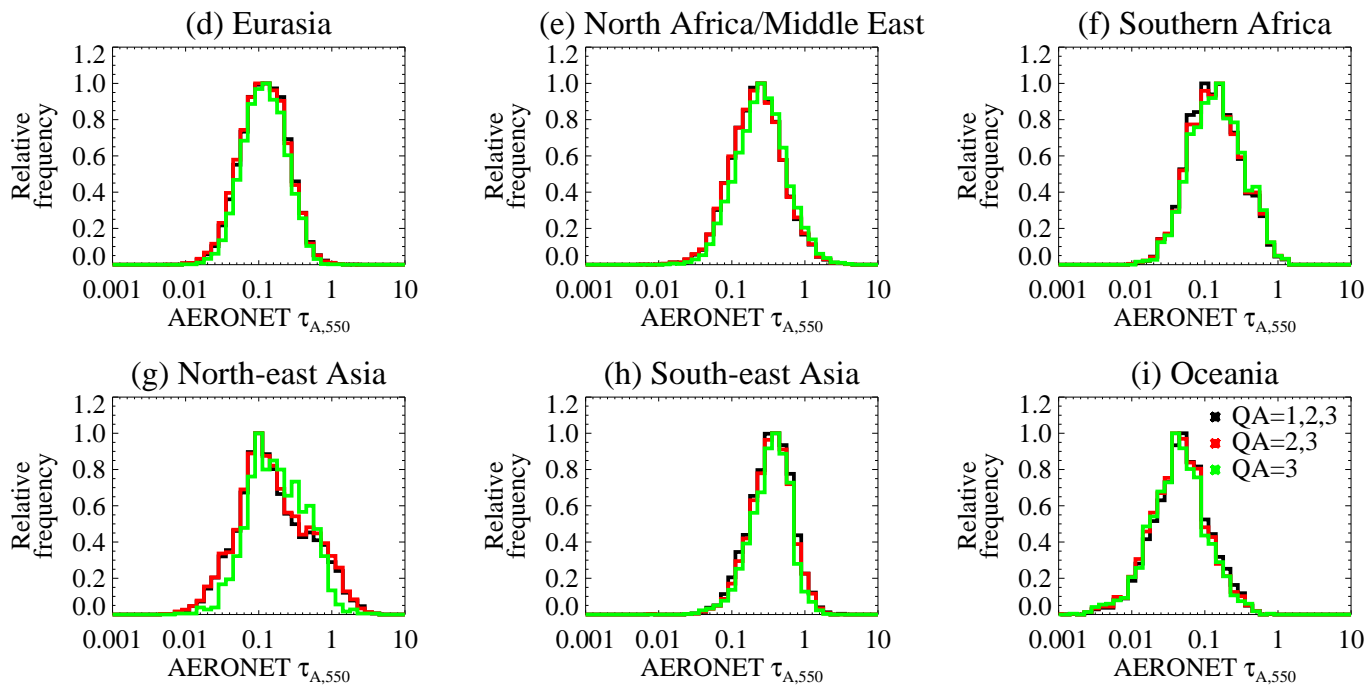

Fig. 3. Histograms of AERONET AOD at $550 \mathrm{~nm}$ obtained from SeaWiFS-AERONET matchups. Each subfigure shows a composite from sites in different regions, as defined in Fig. 1. Black lines show histograms for matchups with all SeaWiFS QA permitted, red lines those matchups obtained using $\mathrm{QA}=2$ or $\mathrm{QA}=3$ retrievals only, and green lines those matchups using $\mathrm{QA}=3$ only.

relative frequency of the lowest $\left(\tau_{\mathrm{A}, 550}<0.05\right)$ and highest $\left(\tau_{\mathrm{A}, 550}>1\right)$ AOD.

\subsection{Effect of spatial averaging}

A further question is whether the spatial averaging of SeaWiFS data is decreasing the apparent error, by averaging out noise in the data. To test this, a more restricted additional comparison was performed, using only SeaWiFS retrievals whose footprint included the AERONET sites directly (i.e., no spatial averaging) and requiring a tighter temporal coincidence of sampling (averaging within $\pm 15 \mathrm{~min}$ rather than 30). The resulting sample size, correlations and fraction within EE are shown in Table 1 for each QA threshold: statistics are very similar to the $25 \mathrm{~km} / 30 \mathrm{~min}$ case, indicating that retrieval noise is a minor component, i.e., most errors in a given region are likely systematic, linked to characterisation of surface and aerosol microphysical properties at that space and time, rather than radiometric. The tighter colocation criteria result in sampling decreasing by approximately half. Therefore, as the statistics of the comparison are similar and the sample size double, the $25 \mathrm{~km} / 30 \mathrm{~min}$ comparisons will be used for the further analysis.

\subsection{Dependence on AOD}

Figure 4 shows the error in the retrieved $\operatorname{AOD}\left(\tau-\tau_{\mathrm{A}}\right)$ binned as a function of $\tau_{\mathrm{A}}$, with lines and shading to indicate different percentiles of the error distribution. For low AODs, the SeaWiFS data have negligible offset. The distribution of retrieval errors in these cases must be biased positive, as retrieval of negative AOD is not permitted. As AOD increases above about 0.5 , at all wavelengths a negative bias of order $15 \%$ is observed. However, for the range of AOD in which the majority of data lie (typically $0.05-0.3$, e.g., Fig. 3), the SeaWiFS data have on average an offset of order 0.02 or less from AERONET. SeaWiFS reports lower $\alpha$ than AERONET for all AOD; as $\alpha$ is fixed at 1 for $\tau_{550}<0.1$ in SeaWiFS, Fig. 4e suggests that $1.5-2$ would be a more appropriate value in these conditions, to give a comparatively unbiased estimate.

One possible explanation for a low bias at high AOD is an underestimation of aerosol absorption. However, as TOA reflectance is not a linear function of AOD, heterogeneity of aerosol on a sub-retrieval scale could also be a factor, particularly close to strong sources (e.g., Alexandrov et al., 2004; Shinozuka and Redemann, 2011). Figure 5 shows TOA reflectance stored in the lookup tables used in the SeaWiFS 

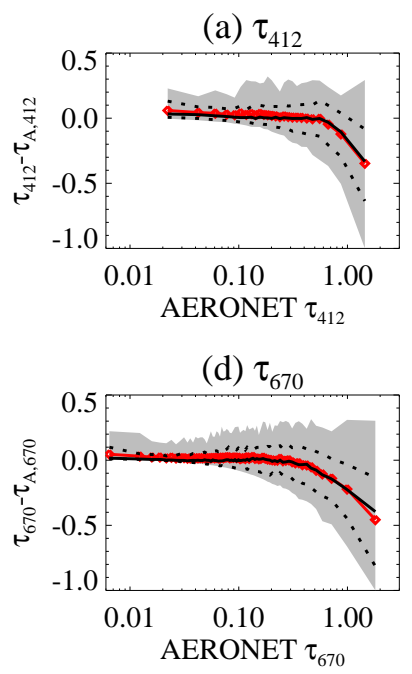

(b) $\tau_{490}$

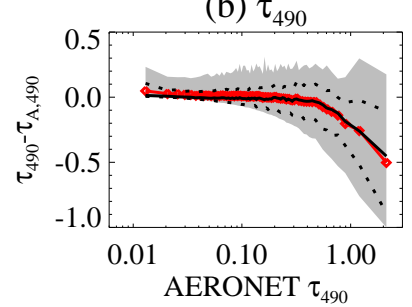

(e) $\alpha$

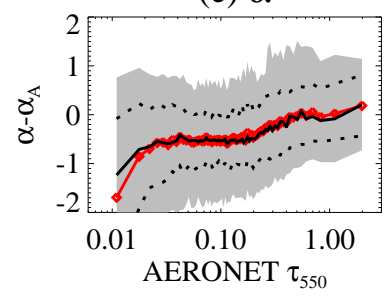

Fig. 4. Retrieval error (SeaWiFS-AERONET) as a function of AERONET AOD, for AOD at (a) $412 \mathrm{~nm}$, (b) $490 \mathrm{~nm}$, (c) $550 \mathrm{~nm}$, (d) $670 \mathrm{~nm}$; (e) Ångström exponent (as a function of AOD at $550 \mathrm{~nm}$ ). In these, data are binned in order of ascending AOD, with a bin size of 500 matchups. In each plot, the red line shows the mean error, the solid black line the median, dotted black lines the 16th and 84th percentiles in that bin (i.e., the $68 \%$ confidence interval), and the shaded grey area the bounds of the 2.5 th and 97.5 th percentiles (i.e., the $95 \%$ confidence interval). Only points where $\mathrm{QA}=3$ are included.
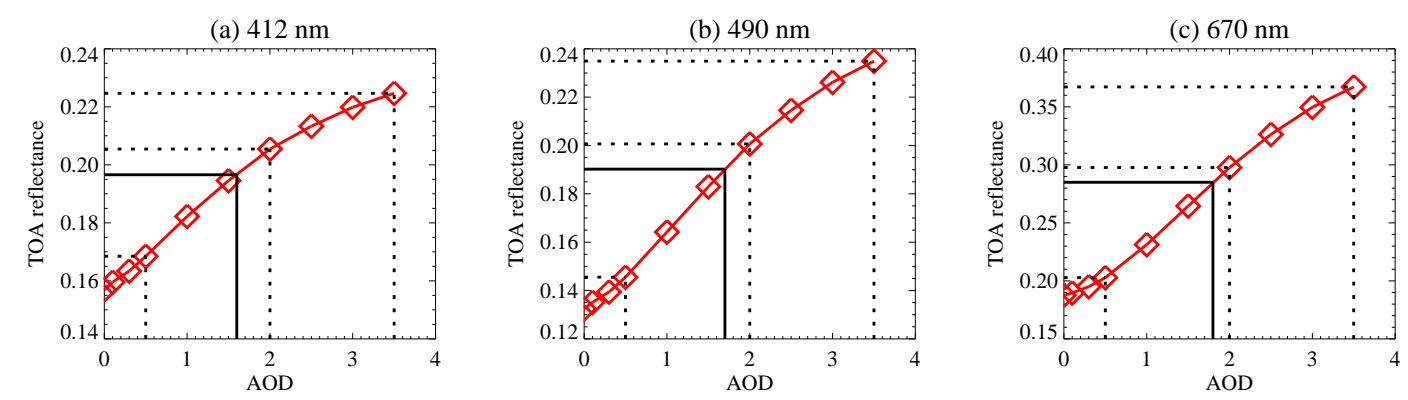

Fig. 5. Response of TOA reflectance to changes in AOD at (a) $412 \mathrm{~nm}$, (b) $490 \mathrm{~nm}$, and (c) $670 \mathrm{~nm}$. Geometry, surface and aerosol microphysical properties were taken as those typically encountered at Banizoumbou by SeaWiFS. The red line indicates the TOA reflectance as a function of AOD at that wavelength. The black dotted lines show the TOA reflectance for AOD of 0.5, 2 and 3.5. The black solid line shows the average of reflectances for $\mathrm{AOD}=0.5$ and $\mathrm{AOD}=3.5$, and the equivalent $\mathrm{AOD}$ for this reflectance.

AOD retrieval (defined as the TOA radiance normalised by the solar irradiance) for typical observing conditions at the AERONET site of Banizoumbou in central Africa. In this figure, solar and viewing zenith angles were taken to be $32^{\circ}$, and the relative azimuth angle $120^{\circ}$. Surface reflectances of 0.06 , 0.1 and 0.2 at $412 \mathrm{~nm}, 490 \mathrm{~nm}$, and $670 \mathrm{~nm}$, respectively, were assumed, together with an absorbing aerosol model to represent biomass burning smoke. Suppose an AOD retrieval is performed on a pixel split in coverage evenly between a thick plume with and AOD of 3.5 and an elevated background AOD of 0.5. In this case, the area-weighted average AOD of the pixel would be 2 . However, because of the nonlinearity, the TOA reflectance of this heterogeneous case does not correspond to the TOA reflectance of a homogeneous scene with an AOD of 2 and, presented with this reflectance, the algorithm would retrieve an AOD of 1.6, 1.7 and 1.8 at $412 \mathrm{~nm}, 490 \mathrm{~nm}$ and $670 \mathrm{~nm}$, respectively. It is a philosophical point whether this should be considered an error or not, and potentially depends on the user's desired application of the data, as the satellite would retrieve the radiative-average AOD rather than the spatial average.

Although this is a single example, it serves to illustrate the potential magnitude of such effects. At high AOD the increase in reflectance with AOD becomes smaller and the curves begin to flatten; the fact that the curvature is of this type suggests that, in a high-AOD case, a negative bias in satellite-retrieved AOD would be more likely than a positive bias. This effect will be an issue for other, similar retrieval algorithms, and it could be ameliorated in the future by sensors with higher spatial resolution, or assuming some degree of spatial heterogeneity in AOD (rather than homogeneity) in the radiative transfer calculations used in such 


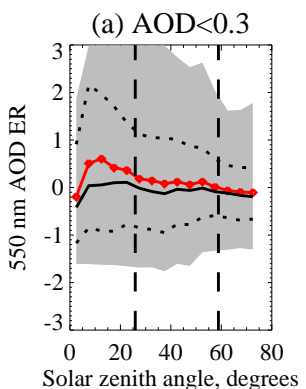

(e) $\mathrm{AOD}>0.3$

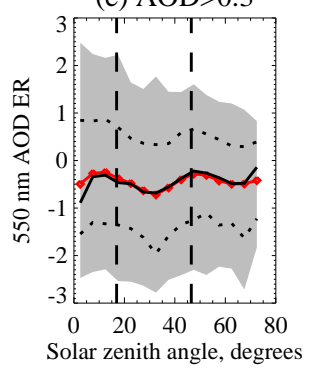

(b) $\mathrm{AOD}<0.3$
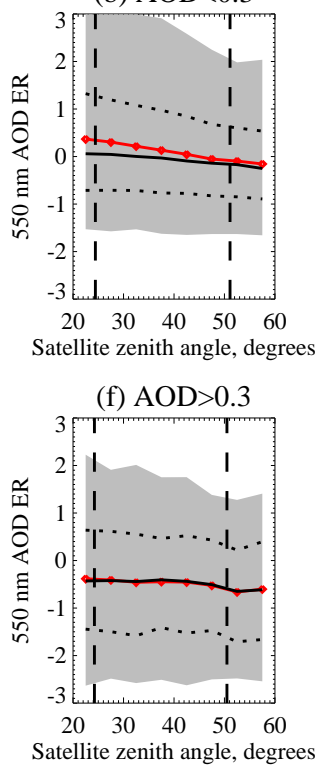

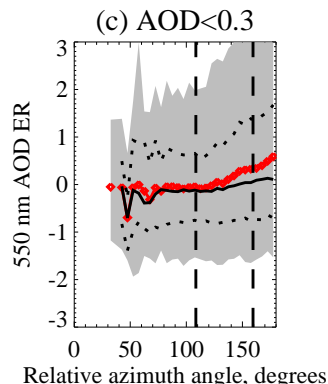

Relative azimuth angle, degrees

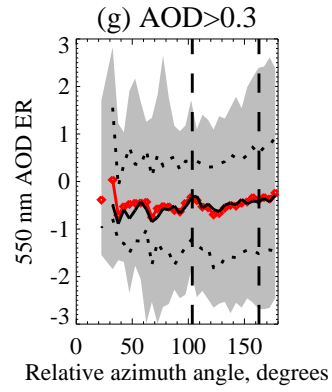

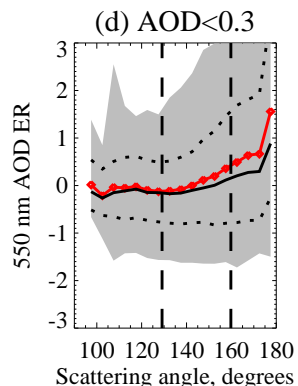

(h) $\mathrm{AOD}>0.3$

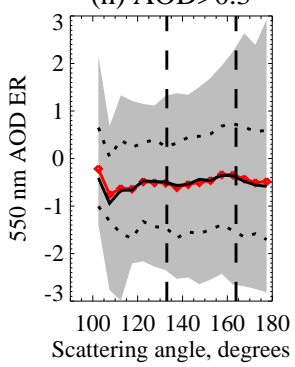

Fig. 6. Retrieval error ratio (ER) at $550 \mathrm{~nm}$, defined as the ratio of the retrieval error to the expected error, as a function of retrieval geometry. The top row shows points where $\tau_{\mathrm{A}, 550}<0.3$, and the bottom row $\tau_{\mathrm{A}, 550}>0.3$. Plots show dependence on (a, e) the solar zenith angle, (b, f) satellite (viewing) zenith angle, (c, g) relative azimuth angle, and (d, h) scattering angle. The bin size is $5^{\circ}$ for each angle, and only bins with 5 or more points are shown. The lines and symbols are as indicated in Fig. 4. Dashed vertical lines show the angular range in which the central $68 \%$ of the data lie. Only points where QA $=3$ are included.

algorithms. The exact error will also be dependent on the spacing of points and interpolation scheme in the radiative transfer lookup tables used in the retrieval.

As $\alpha$ can be used as a first-order indication of aerosol type/size (e.g., Eck et al., 1999), the ER at $550 \mathrm{~nm}$ was also examined as a function of $\alpha_{\mathrm{A}}$ (not shown). Only points where $\tau_{\mathrm{A}, 550}>0.3$ were used, both to ensure the utility of $\alpha_{\mathrm{A}}$, and as the notion of a dominant aerosol "type" is more meaningful when AOD is elevated significantly above typical background values. No clear dependence of ER on $\alpha_{\mathrm{A}}$ was found, suggesting that the underestimate of AOD for conditions of high aerosol loading occurs for all aerosol types.

\subsection{Geometric dependence}

The ER is shown as a function of retrieval geometry in Fig. 6, split into low-AOD conditions $\left(\tau_{\mathrm{A}, 550}<0.3\right)$ where surface reflectance assumptions are expected to be the dominant source of uncertainty, and high-AOD conditions $\left(\tau_{\mathrm{A}, 550}>0.3\right)$, where aerosol microphysical property assumptions are expected to dominate. The distributions of ER show some similarities in both groupings. When the atmospheric path length of reflected radiance is small (e.g., highsun, near-nadir observations), the $95 \%$ confidence interval is wider, particularly on the positive-ER side. The contribution of the aerosol to the TOA signal will be smaller in these cases, and cloud detection also more difficult; further, this geometry is most frequently encountered in tropical regions, which more often have bright reflecting surfaces (e.g., the Sahara desert). The difference between the mean and median ER also becomes larger under these geometric conditions for low AOD, further indicative of stronger positive outliers.

A positive bias in AOD as the viewing geometry approaches backscatter is observable in low-AOD cases (Fig. 6d), but not high-AOD cases (Fig. 6h). This suggests that the surface reflectance models used in the SeaWiFS retrieval underestimate the "hotspot" effect (e.g., Chen and Cihlar, 1997) observed near the backscattering direction and is, therefore, one avenue for improvement in future versions of the dataset. However, the bulk of the data lie at smaller scattering angles than those where this bias is largest $\left(170^{\circ}\right.$ and greater).

Figure 6e reveals an oscillation of ER with solar zenith angle, for $\tau_{\mathrm{A}, 550}>0.3$. The reasons for this are at present unclear; examining the statistics on a regional basis (not shown) suggests the pattern is largely from matchups over the North Africa/Middle East, and South-East Asia regions, suggesting it could be linked to errors in dust or mixed dust/smoke phase functions at specific geometries. Finally, for both low-AOD and high-AOD cases, there is a small tendency for the ER to become more negative with increasing viewing zenith angle. However, the most dramatic angle-dependent effects appear to be associated with high-Sun conditions and retrievals close to the backscattering direction. 
(a) Mean AERONET $550 \mathrm{~nm}$ AOD

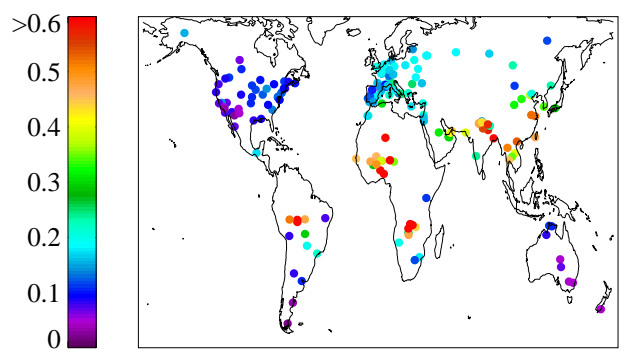

(c) Correlation coefficient, $550 \mathrm{~nm}$

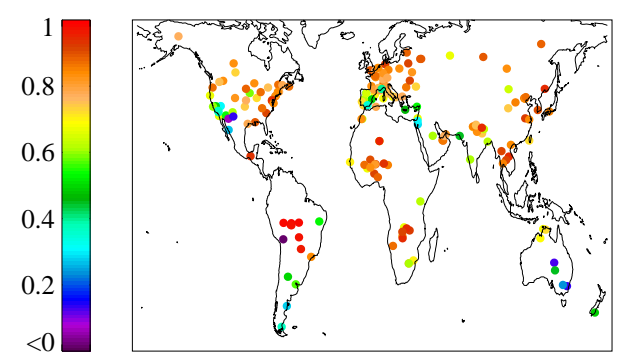

(b) Fraction within expected error, $550 \mathrm{~nm}$

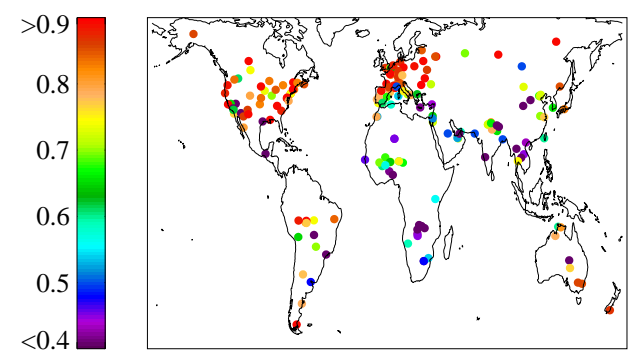

(d) Median bias, $550 \mathrm{~nm}$

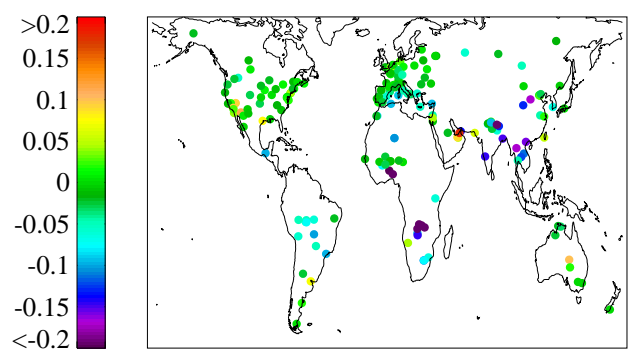

Fig. 7. Statistics related to AERONET $550 \mathrm{~nm}$ AOD comparison at each site considered: (a) mean AERONET AOD; (b) fraction of comparisons within the expected error $\left(0.05+0.2 \tau_{\mathrm{A}, 550}\right)$; (c) Pearson's linear correlation coefficient between the matched data; and (d) median (SeaWiFS-AERONET) AOD bias.

\subsection{Temporal dependence}

The $0.3 \%$ radiometric stability of SeaWiFS calibration (Eplee Jr. et al., 2011) should translate into potential artificial trends in retrieved AOD smaller than 0.01 across the mission. The retrieval stability may differ from this if nonradiometric factors (e.g., applicability of assumptions made about surface reflectance or aerosol microphysical properties) change through time. This can be assessed by examining the change in ER as a function of time in comparisons against AERONET, an approach taken by Levy et al. (2010) when validating the MODIS "Dark Target" dataset. Only the subset of AERONET sites including data spanning at least a ten-year time period (Alta Floresta, Avignon, Banizoumbou, Beijing, Bondville, Bratts Lake, CART Site, Dakar, Dalanzadgad, GSFC, HJ Andrews, Ilorin, IMS METU-Erdemli, Ispra, Kanpur, MD Science Center, Mongu, Sede Boker, Sevilleta, Skukuza, Solar Village, Wallops) are used. Restricting to sites with a long time series helps to ensure that changes in the population of available AERONET sites between years do not influence the apparent trend in ER.

Examining the ER against time for these sites (omitted for brevity) reveals no obvious trends. Performing a linear regression of the mean ER against year gives a gradient of $0.0112 \pm 0.0074$ (in units of ER per year); assuming a typical $\tau_{550} \approx 0.15$ (the mean and median AERONET values for the colocated data are 0.21 and 0.13 , respectively) gives an estimate of a total drift of $0.0114 \pm 0.0075$ (in units of AOD) over the 13-yr length of the dataset. Quoted trend uncertainties are the one-sigma uncertainty on the fit. These values are not significant at the $90 \%$ level, suggesting that if these long-term sites are representative of the SeaWiFS dataset as a whole, then there is not a statistically-significant linear change in the quality of the data with time, which is an important step in determining the utility of the dataset for trend analysis.

\section{Regional comparisons}

The previous sections have established the utility of the SeaWiFS data on a global basis. However, due to differences in aerosol and surface properties (as well as observation geometry) in different parts of the world, it is logical to examine the data on a regional basis. This will aid the understanding of researchers interested in studies of a regional nature. To this end, Fig. 7 maps various statistics related to the comparison with AERONET data at the different sites. Table 2 presents statistics of the SeaWiFS/AERONET comparison on a regional basis.

Figure 8 shows the seasonal variability of SeaWiFS $\tau_{550}$, alongside the difference between SeaWiFS and the other satellite datasets considered. Images from MODIS Terra are omitted for brevity, as patterns were found to be very close to those from MODIS Aqua in most cases. The difference images have been resampled to $3^{\circ}$ horizontal resolution for ease 
(a) SeaWiFS $\tau_{550}$, DJF

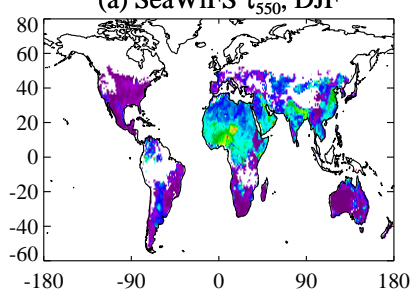

(e) SeaWiFS-MISR

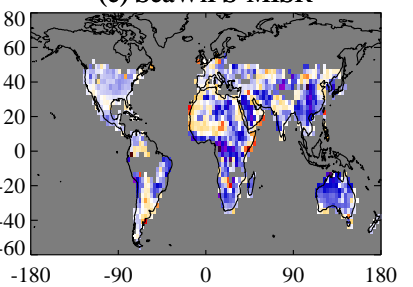

(i) SeaWiFS-MODIS (Aqua)

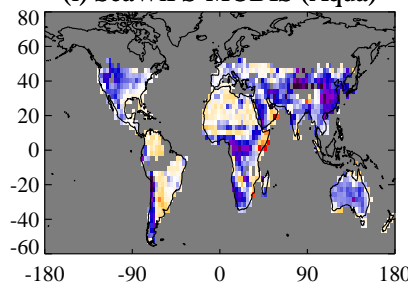

(m) SeaWiFS-DA MODIS (Aqua)
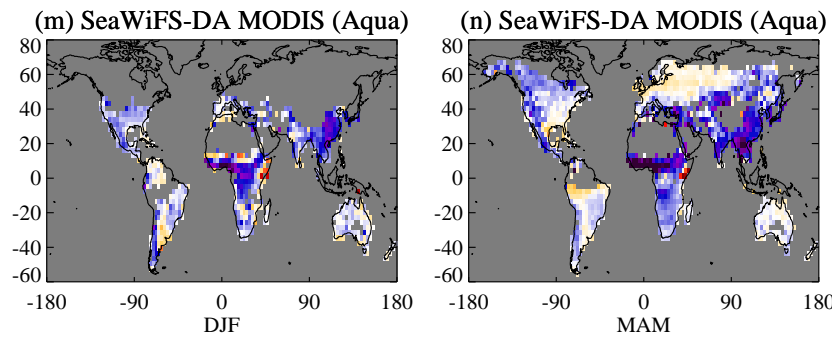

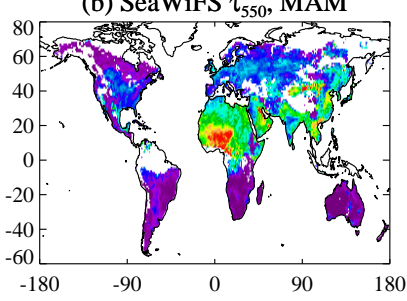

(f) SeaWiFS-MISR

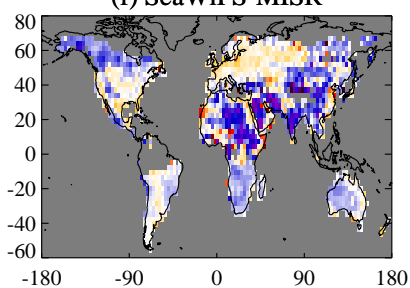

(j) SeaWiFS-MODIS (Aqua)

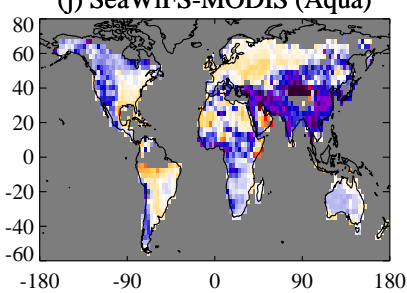$$
\text { . }
$$

(c) SeaWiFS $\tau_{550}$, JJA

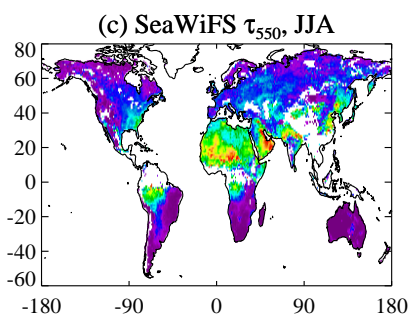

(g) SeaWiFS-MISR

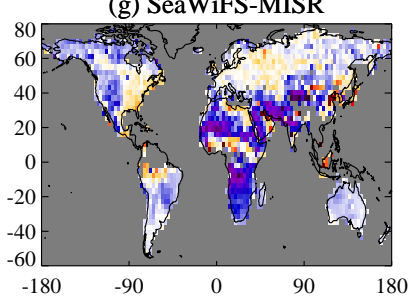

(k) SeaWiFS-MODIS (Aqua)

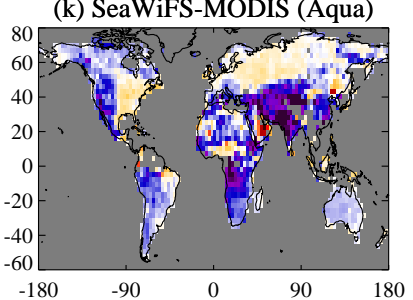

(o) SeaWiFS-DA MODIS (Aqua)

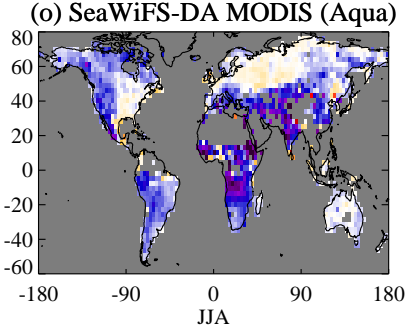

(d) SeaWiFS $\tau_{550}$, SON

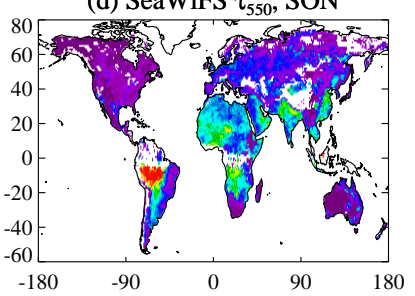

(h) SeaWiFS-MISR

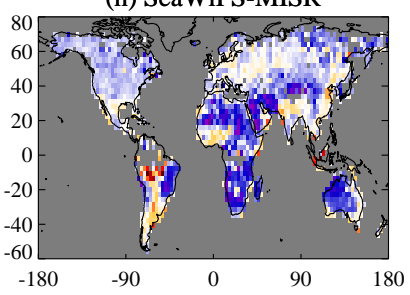

(1) SeaWiFS-MODIS (Aqua)

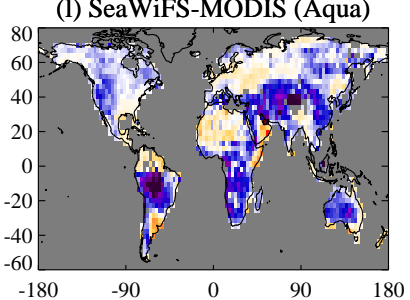

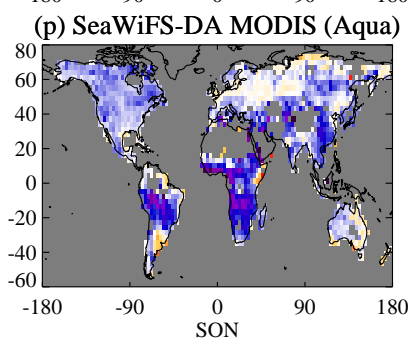
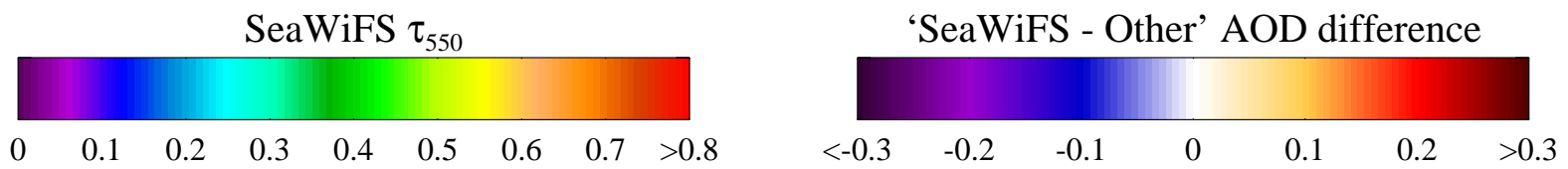

Fig. 8. Comparison between seasonal mean colocated SeaWiFS AOD at $550 \mathrm{~nm}$ and other satellite datasets. From left to right, columns indicate the seasons December-January-February (DJF), March-April-May (MAM), June-July-August (JJA), and September-October-November (SON). The top row shows (a-d) SeaWiFS seasonal mean AOD. Successive rows show the difference in seasonal mean AOD from colocated data between SeaWiFS and (e-h) MISR; (i-l) MODIS (Aqua); and (m-p) DA-MODIS (Aqua).

of visualisation, and offsets between the datasets were largely observed to be spatially coherent on these scales. However, all statistics presented herein are calculated at full $\left(0.5^{\circ}\right.$ or $\left.1^{\circ}\right)$ Level 3 resolution.

Table 3 shows the correlation, bias and scaled median absolute deviation $\left(\sigma_{\mathrm{med}}\right)$ about the median difference in $\tau_{550}$, defined $\sigma_{\text {med }}(x)=\beta(\widetilde{x-\tilde{x}})$, where $\sim$ indicates a median quantity and $\beta$ is a scaling factor. If the underlying distribution is Gaussian, then $\sigma_{\text {med }}$ is equivalent to standard deviation for $\beta=1.4826$, which is assumed here. This quantity is discussed further by Sayer et al. (2012). These statistics are provided on a global scale (regional correlations are provided later), and reveal a high level of agreement, although a relative negative offset between 0.015 and 0.029 on a global basis. Note that it is not appropriate to consider a fraction within expected error for the inter-satellite comparisons. Reasons for this include the fact that none of the satellite datasets can be considered to provide a "ground truth"; that some scatter is to be expected because of changes in aerosol loading between the overpasses of the different instruments; that there are differences in spatial sampling between the datasets (even though the methodology aims to minimise these); and that the expected error for individual retrievals from each dataset cannot be propagated into a Level 3 expected error, as it is 
Table 2. Statistics of validation of spectral AOD with AERONET data. Sites are subset according to geographic region (Fig. 1). $R$ is Pearson's linear correlation coefficient.

\begin{tabular}{|c|c|c|c|c|c|c|c|c|c|c|c|c|c|}
\hline \multirow[t]{2}{*}{ Region } & \multirow{2}{*}{$\begin{array}{r}\text { Number } \\
\text { of } \\
\text { sites }\end{array}$} & \multicolumn{4}{|c|}{$\begin{array}{l}\text { Number of matchups } \\
\text { Wavelength, nm }\end{array}$} & \multicolumn{4}{|c|}{$\begin{array}{c}R \\
\text { Wavelength, nm }\end{array}$} & \multicolumn{4}{|c|}{$\begin{array}{l}\text { Fraction within EE } \\
\text { Wavelength, nm }\end{array}$} \\
\hline & & 412 & 490 & 550 & 670 & 412 & 490 & 550 & 670 & 412 & 490 & 550 & 670 \\
\hline Western North America & 20 & 1011 & 4935 & 4937 & 4938 & 0.74 & 0.64 & 0.60 & 0.50 & 0.74 & 0.68 & 0.72 & 0.74 \\
\hline Central/South America & 15 & 443 & 2178 & 2179 & 2179 & 0.95 & 0.96 & 0.96 & 0.93 & 0.75 & 0.63 & 0.67 & 0.73 \\
\hline Eurasia & 48 & 4413 & 8937 & 8937 & 8937 & 0.84 & 0.83 & 0.82 & 0.77 & 0.80 & 0.82 & 0.84 & 0.80 \\
\hline Southern Africa & 11 & 3 & 1663 & 1663 & 1663 & 0.10 & 0.81 & 0.79 & 0.74 & 0.33 & 0.41 & 0.46 & 0.52 \\
\hline North-east Asia & 9 & 723 & 1637 & 1637 & 1637 & 0.88 & 0.87 & 0.86 & 0.83 & 0.79 & 0.73 & 0.72 & 0.66 \\
\hline South-east Asia & 22 & 902 & 1879 & 1879 & 1879 & 0.81 & 0.81 & 0.80 & 0.80 & 0.71 & 0.63 & 0.61 & 0.53 \\
\hline Oceania & 8 & 606 & 1813 & 1811 & 1811 & 0.22 & 0.37 & 0.35 & 0.32 & 0.62 & 0.70 & 0.71 & 0.72 \\
\hline
\end{tabular}

(a) Eastern North America

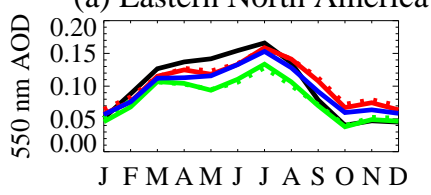

(d) Eurasia

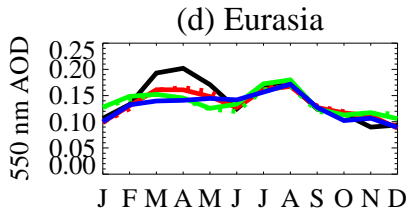

(g) North-east Asia

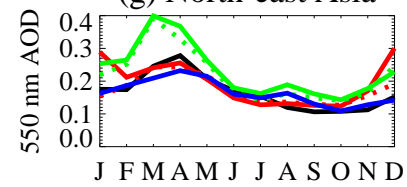

(b) Western North America

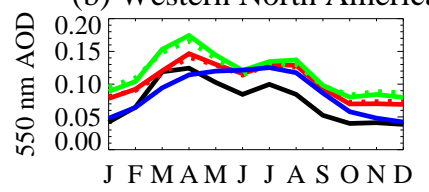

(e) North Africa/Middle East

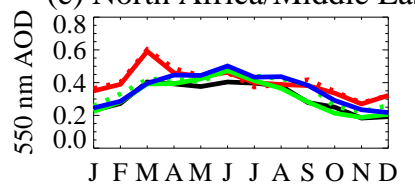

(h) South-east Asia

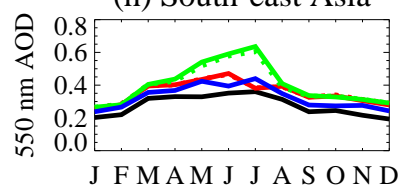

(c) Central/South America

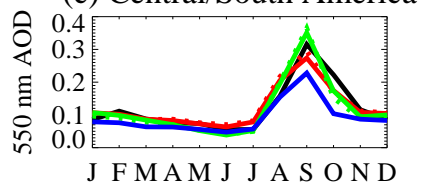

(f) Southern Africa

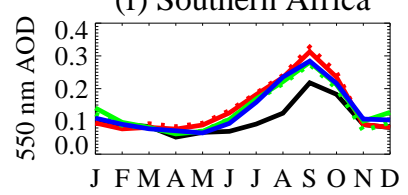

(i) Oceania

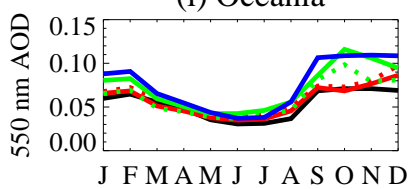

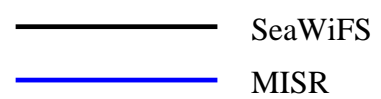

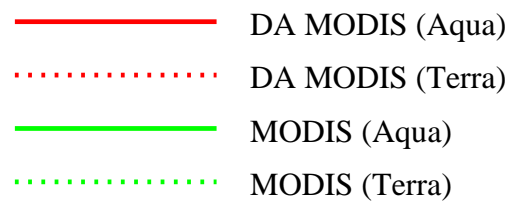

Fig. 9. Annual cycles of $550 \mathrm{~nm}$ AOD from the satellite datasets, for each region. Month names are abbreviated using their first letters, in order January-December.

uncertain which components of the retrieval error are a result of random error and which are systematic biases for any given point.

The annual cycle of $550 \mathrm{~nm}$ AOD is shown in Fig. 9 for each region. In this figure, the MODIS, DA-MODIS and MISR data are drawn from the set of colocated daily measurements described in Sect. 2.3. For simplicity, the SeaWiFS data are a multiannual (2006-2010) monthly mean in each region (as otherwise the plots would require one SeaWiFS line to correspond with each of the colocated datasets). Note that this means the spatial sampling may differ between the datasets. In particular, DA-MODIS lacks coverage over bright surfaces. This figure also illustrates the similarity between Terra and Aqua data, for the MODIS and DA-MODIS datasets. Together with the results of Smirnov et al. (2002), this supports the idea that differences in local overpass time (between 10:30 a.m. for the Terra plaform, and 01:30 p.m. for 


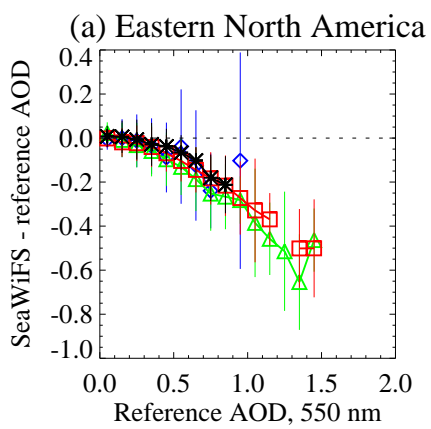

(d) Eurasia

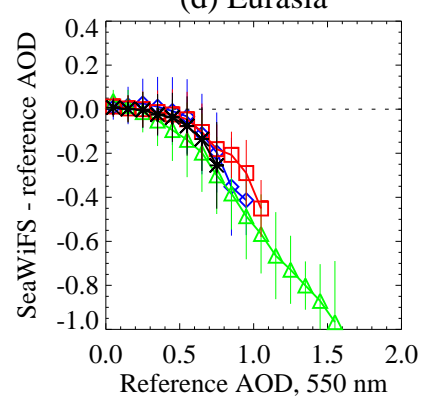

(g) North-east Asia

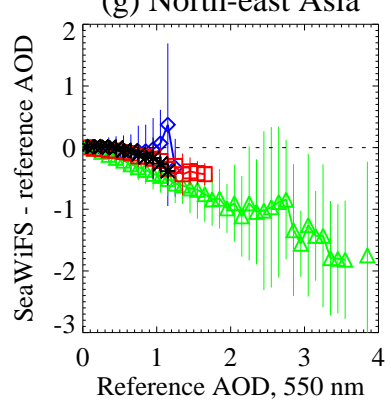

(b) Western North America

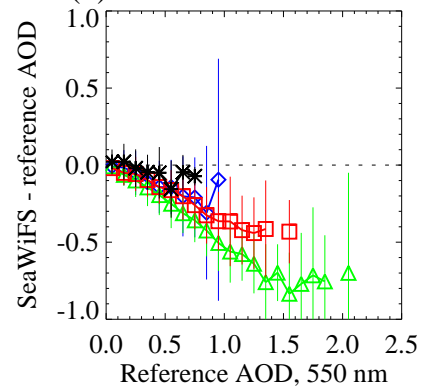

(e) North Africa/Middle East

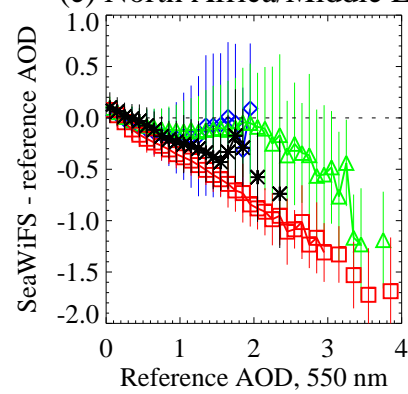

(h) South-east Asia

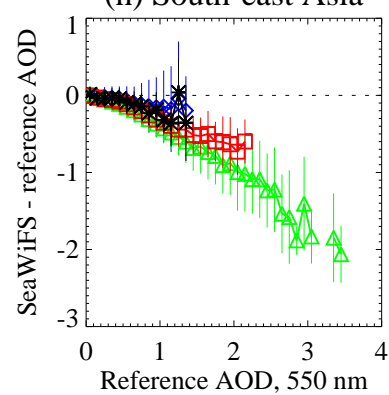

(c) Central/South America

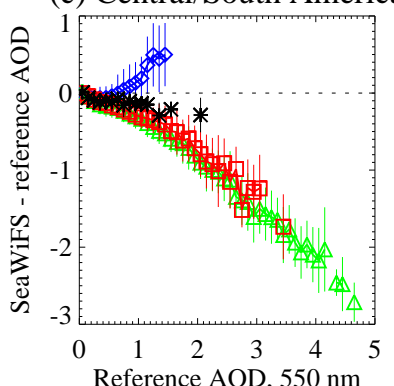

(f) Southern Africa

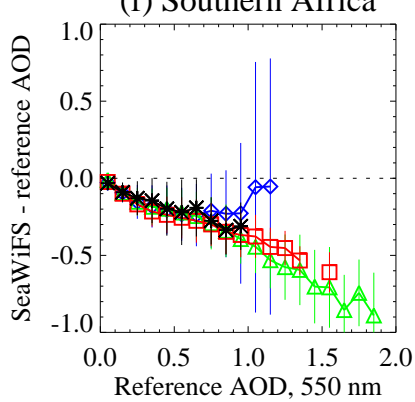

(i) Oceania

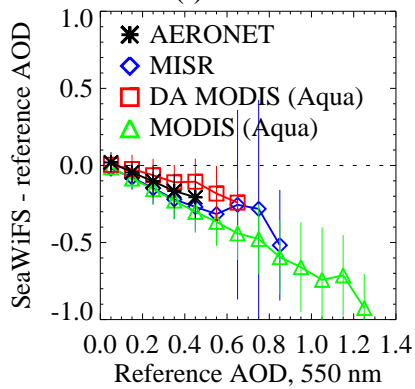

Fig. 10. Comparison between colocated SeaWiFS and other AOD data for each region (Fig. 1). Reference AOD datasets are binned in AOD increments of 0.1; symbols and lines show the mean and standard deviation of the difference between SeaWiFS and the reference AOD in each bin. Data are only shown for bins with at least five matched data points.

Table 3. Statistics of comparison between colocated SeaWiFS daily-averaged AOD at $550 \mathrm{~nm}$ with that from other datasets. Only grid cells over land are considered. $R$ is Pearson's linear correlation coefficient between the grid-box average values. The bias is the median bias between the daily average values, defined such that positive values indicate SeaWiFS AODs are larger. The scaled median absolute deviation of the difference between the two datasets is denoted $\sigma_{\text {med }}$.

\begin{tabular}{lrccc}
\hline Dataset & Number of grid cells & $R$ & Bias & $\sigma_{\text {med }}$ \\
\hline MISR & 1169582 & 0.76 & -0.027 & 0.076 \\
MODIS (Aqua) & 1888154 & 0.81 & -0.015 & 0.081 \\
MODIS (Terra) & 1563994 & 0.80 & -0.019 & 0.080 \\
DA-MODIS (Aqua) & 831335 & 0.85 & -0.026 & 0.060 \\
DA-MODIS (Terra) & 843381 & 0.82 & -0.029 & 0.065 \\
\hline
\end{tabular}

Aqua) are unlikely to lead to significant systematic differences between the datasets considered here.

Finally, Fig. 10 shows the AOD-dependence of the difference between SeaWiFS AOD and the other datasets (AERONET, MISR, MODIS, DA-MODIS) for each of the nine regions described in Fig. 1. A caveat here is, again, that the spatial extent of the area of each region which is sampled by AERONET is smaller than that covered by the satellites. The SeaWiFS/AERONET comparison are drawn from the set of matchups on an instantaneous basis $(25 \mathrm{~km} / 30 \mathrm{~min}$ averaging), while the satellite intercomparisons are from the colocated daily Level 3 data. One immediately obvious point is that the set of AERONET matchups does not extend to the highest AODs which are found in the matched SeaWiFS/MODIS data, and so the opportunities for ground truth in these extreme conditions are limited. However, the total number of such cases is low (the majority of points are 
for $\tau_{550}<0.3$, where biases between the datasets tend to be small).

In the interests of brevity, trends in the SeaWiFS time series are not discussed here. A trend analysis of the SeaWiFS data, in conjunction with AERONET and other satellite datasets, has been performed by Hsu et al. (2012).

\subsection{Eastern North America}

This region is characterised by low AOD (mean $\tau_{\mathrm{A}, 550} \approx 0.1$ at all AERONET sites; Fig. 7) and largely vegetated surfaces. Despite the low AOD, correlations between SeaWiFS and the other datasets are fairly strong, from 0.67 for SeaWiFS/MISR to 0.8 for SeaWiFS/AERONET. The fraction of SeaWiFS/AERONET matchups within EE is well in excess of $68 \%$ in this region. All datasets show a similar seasonality, with spring and summer peaks in AOD and a drop in autumn and winter (Fig. 9). The offset between SeaWiFS and other datasets is small (within 0.02), spatially fairly coherent (Fig. 8) and shows seasonal variation (positive offset in JJA, negative in DJF and SON, variable in MAM) such that SeaWiFS exhibits a stronger seasonality in AOD. The consistency between sensors of the seasonal variability in the offset may reflect deficiencies in the seasonality of the surface reflectance assumed in SeaWiFS, as the low AOD means that the dominant uncertainty source is likely to be surface reflectance assumptions. For $\tau_{550}>0.4 \mathrm{SeaWiFS}$ underestimates AOD relative to AERONET, MODIS and DAMODIS, although these cases account for a small minority of the data.

\subsection{Western North America}

The comparisons within this region are similar to Eastern North America, although part of the region is covered by bare (arid or mountainous) terrain, over which AOD retrieval is more challenging. For the region as a whole, $72 \%$ of SeaWiFS/AERONET matchups are within the EE. The arid parts of this region contain AERONET sites where SeaWiFS compares more poorly (notably Frenchman Flat and Rogers Dry Lake, both dry lake beds); SeaWiFS also tends to overestimate AOD relative to AERONET, MISR and DA-MODIS for these arid areas. The negative offset of SeaWiFS against MODIS suggests MODIS may also be overestimating AOD for part of this region, which is consistent with the analysis of Levy et al. (2010). Seasonality is similar to Eastern North America, although here the spring peak in AOD is more pronounced and is again generally consistent between sensors (Fig. 9).

\subsection{Central/South America}

The AOD in the Central/South America region shows regional and seasonal diversity. High AOD is observed from seasonal biomass burning in the Amazon (AERONET sites of Rio Branco, Abracos Hill, and Rio de Janeiro), which are reproduced well in all datasets, leading to a high level of correspondence. SeaWiFS underestimates AOD for the highest-AOD cases relative to AERONET, MODIS and DAMODIS, and overestimates relative to MISR, which is consistent with known validation results of these datasets (e.g., Kahn et al., 2010; Levy et al., 2010). Direct inter-satellite comparisons in the heart of the Amazon are sparse due to frequent cloud cover, with significant variability between midmorning and early afternoon (Meskhidze et al., 2009), which limits sampling.

Away from biomass burning, lower $\operatorname{AOD}\left(\tau_{\mathrm{A}, 550} \approx 0.2\right)$ is found in urban AERONET sites in Mexico and Brazil. Although well-correlated, SeaWiFS has a low offset relative to AERONET for these sites. This offset is also observed when comparing with the other satellite datasets, and suggests an overestimation of surface reflectance in urban areas in this region. Finally, the southern part of this region has lower AOD still $\left(\tau_{\mathrm{A}, 550}<0.1\right)$; the correlation between SeaWiFS and AERONET is low for these sites, as the range of AOD encountered is comparable to the uncertainty on the retrieval, although the fraction within EE is large. The area around Buenos Aires is an exception to this, as SeaWiFS has a positive offset relative to the other datasets.

\subsection{Eurasia}

Similar to Eastern North America, AERONET sites within Eurasia are largely found in suburban or agricultural regions with a low-AOD background, vegetated surfaces and AOD peaks in spring and summer. Again, $84 \%$ of matches with AERONET are within the EE. The offset between SeaWiFS and other datasets again varies seasonally within the region, generally positive for the more vegetated parts and negative for the less vegetated parts, but is typically of order 0.02 or less. It is most pronounced in springtime, where SeaWiFS AOD is higher than the other satellites by up to 0.05 , but otherwise the seasonality of AOD tracks well. This region contains almost $25 \%$ of all global matches between SeaWiFS and AERONET, so weighs heavily in the global statistics.

\subsection{North Africa/Middle East}

The aerosol burden in this region is largely composed of wind-blown mineral dust (with particular hotspots in the Bodélé Depression and western Sahara desert), with additional contributions from biomass burning and anthropogenic emissions (Prospero et al., 2002; Knippertz and Todd, 2012). The majority of the surface is bare and bright, although the Sahel and savannas towards the southern end are more vegetated, as are some coastal portions. It should be noted that coverage of DA-MODIS is particularly sparse in this region, as the DA-MODIS dataset is drawn only from the Dark Target MODIS product, which lacks coverage over bright surfaces (as noted in Sect. 2, Deep Blue data provide coverage 
in arid regions in the standard MODIS product). Retrieval of AOD from satellite data is challenging in this region due to the bright surfaces, mountainous terrain, complicated aerosol microphysical properties (e.g., Kalashnikova et al., 2005; Dubovik et al., 2006), and remoteness of locations meaning that many parts of the region are not well-covered by ground measurements (Fig. 7). Because of the sampling issues, interpretation of the seasonal cycle in this region is difficult, although SeaWiFS, MISR, and MODIS all show peaks from May to July and a minimum from October to February, with a range of around 0.2 through the year.

Although well-correlated overall, at several of sites the proportion of SeaWiFS/AERONET matches within EE at $550 \mathrm{~nm}$ is 0.5 or less, in which cases SeaWiFS underestimates AOD. For the region as a whole, it is 0.58. Spatial patterns of the relative offset between SeaWiFS and other satellites vary seasonally, up to \pm 0.3 in some locations, and are not always consistent between the sensors. In general, for the highest AODs, SeaWiFS is higher than MISR, similar to MODIS, and lower than DA-MODIS, albeit with significant scatter in all cases. Examination of the surface reflectances retrieved by MISR and assumed by SeaWiFS in this region (not shown) reveals spatial patterns in close correspondence, which suggests that this is not the primary cause for regionally-varying offsets between the two. SeaWiFS AOD is lower than MISR over mountainous terrain; retrieval algorithm uncertainties related to elevation are likely to affect SeaWiFS more strongly than MISR (as the former relies more heavily on violet and blue wavelengths), so this may indicate a low-bias of SeaWiFS over mountains. SeaWiFS being higher than MISR for high AOD is consistent with known MISR validation results (Kahn et al., 2010). Comparing SeaWiFS and MODIS over the desert is less instructive because they share the Deep Blue algorithm approach (although the application to SeaWiFS introduces some updates over the algorithm applied in the Collection 5 MODIS product, particularly in terms of surface reflectance).

Due to the difficulty in accurate AOD retrieval here and sparseness of ground measurements, it is difficult to assess with confidence which dataset(s) are closest to the truth, and it is likely that without more advanced sensors and/or algorithms this will continue for the near future. Users are, therefore, advised to be aware of the differences between satellite AOD datasets in this region.

\subsection{Southern Africa}

Southern Africa is more influenced by biomass burning and less by mineral dust than the North Africa/Middle East region (Swap et al., 1996; Prospero et al., 2002, and references therein), although similar considerations about semi-arid and elevated terrain, and complexity of aerosol microphysical properties, remain. Only $46 \%$ of SeaWiFS/AERONET matches at $550 \mathrm{~nm}$ are within the EE. The most poorlyperforming sites in this region are biomass burning sites in
Zambia, where SeaWiFS underestimates AOD by $0.1-0.2$; it is possible that some of this is due to heterogeneity of aerosol near sources (e.g., Sect. 3). However, Figs. 8 and 10 reveal that aside from at low-lying coastal regions, SeaWiFS AOD is generally negatively offset by between 0.05 and 0.25 compared to other satellites and AERONET even in lowAOD cases, which suggests an overestimation of surface reflectance. This could also indicate that the simple way in which terrain elevation is treated in the current version of the algorithm is inadequate in this region, where the majority of the terrain is at an altitude of $1 \mathrm{~km}$ or more above sea level. The same comments as made for seasonality of AOD in Central/South America are applicable here.

\subsection{North-Eastern Asia}

AERONET sites in this region are split between fairly highAOD regions in industrialised China, the Gobi Desert and vegetation in Siberia; coverage is sparse for these latter two cases. On the whole, $72 \%$ of matches are within the EE. Performance at Irkutsk in Siberia is poor (50\% in EE), but this is in a valley in mountainous terrain, and only 10 matchups were obtained. At Yulin, only $28 \%$ are within the EE; this is an elevated site, within a city surrounded by arid terrain. Again, at these sites, SeaWiFS is more likely to underestimate than overestimate AOD. The majority of points are from sites where the AOD is dominated by urban pollution and dust, at which the level of agreement is good, contributing to the correlation with AERONET of 0.86 for the region as a whole.

Due to seasonal cloud, snow cover, mountainous terrain and bright desert surfaces, the majority of satellite data points in this region are in northern China and North/South Korea, with much of Mongolia, Japan and Russia more sparsely covered. There is little net bias between SeaWiFS and MISR or DA-MODIS, although spatially-coherent biases in parts of the region contribute to scatter in Fig. 10, particularly in the comparison with MISR. SeaWiFS has a more negative bias relative to MODIS, with the strongest outliers in the Taklimakan Desert. SeaWiFS exhibits a similar, but less negative, offset relative to MISR in this location. Unfortunately, there are no AERONET data available in the Taklimakan. SeaWiFS, MISR, and DA-MODIS all show a peak in AOD from March to May around 0.25 , followed by AOD around 0.15 later in the year. This spring peak is strongly enhanced in the MODIS data. MODIS and DA-MODIS also have a secondary peak in December and January, absent from the other satellite datasets.

\subsection{South-Eastern Asia}

Much of this region consists of agricultural land, interspersed with densely-populated cities, in which most of the AERONET sites are found. The aerosol loading is linked with large-scale meteorology and seasonality differs between 
the Indian subcontinent and the eastern end of the region. In the Indian pre-monsoon (April-June), westerly winds blow dust across the Indo-Gangetic plain, where it is trapped by the Himalayas; the winter monsoon is associated with fog and thick haze from urban pollution and biomass burning aerosols (Prospero et al., 2002; Gautam et al., 2007, 2010, 2011). Over the Indo-China peninsula, intense biomass burning during the pre-monsoon (February-April), in combination with urban emissions, leads to an optically-thick absorbing haze layer (Carmichael et al., 2003; See et al., 2006); monsoon rains during the summer washout much of the aerosol and cloud cover limits SeaWiFS's coverage. Similarly, near-persistent cloud cover means SeaWiFS coverage over Indonesia is sparse.

SeaWiFS is well-correlated with the other datasets in this region (Figs. 7 and 10), although only $61 \%$ of matches with AERONET are within the EE, as SeaWiFS has a low relative bias, for all AOD. Compared to the other satellites, SeaWiFS tends to retrieve lower AOD at those times and locations when very absorbing aerosols are present, which, in combination with the AERONET results, suggests the aerosol microphysical models used may be insufficiently absorbing. SeaWiFS retrieves higher AOD than MISR over much of the Indo-Gangetic Plain in all seasons; the low bias of MISR with respect to AERONET and MODIS over parts of this region has previously been noted (Kahn et al., 2009, 2010). Over the region as a whole, SeaWiFS, MISR, and DA-MODIS show AOD higher by $0.1-0.2$ between March and August, relative to the September-February period. As in North-Eastern Asia, this peak is much stronger in the MODIS data.

\subsection{Oceania}

Although the correlation between SeaWiFS and other datasets is low in Oceania (Fig. 7), this is because the AOD is reported as persistently low by all datasets, such that the typical range of AOD encountered is similar to the typical spread of systematic biases over the region. AOD varies between around 0.04-0.05 (March-August) to 0.060.12 (September-February); offsets between datasets are larger during this second period. Overall, $71 \%$ of SeaWiFS/AERONET matches are within the EE. The one poorlyperforming site is Birdsville, at which SeaWiFS overestimates AOD during all seasons, suggesting an underestimate of surface reflectance. Comparisons with MODIS and MISR reveal a negative offset of SeaWiFS in DJF and SON over the desert regions central and western Australia (of order -0.1); however, in comparison with the DA-MODIS dataset, the offset is near-zero in many locations, and data are absent in others. Unfortunately, there are no AERONET sites in these remote locations.

\section{Conclusions}

As the remote sensing of aerosol optical depth from space continues to be a challenging problem, it is useful that new datasets be validated against ground-truth data and compared with other similar satellite datasets, to gain an understanding of their strengths and shortcomings. This study has performed such an evaluation for a new 13-yr AOD dataset from SeaWiFS over land (the over-water component of the dataset is discussed in Sayer et al., 2012). The main results of the study are as follows:

- On a global basis, $72 \%$ of comparisons between SeaWiFS and AERONET AOD at $550 \mathrm{~nm}$ had an absolute difference within the expected error of $0.05+0.2 \tau_{\mathrm{A}, 550}$, when only data with the highest SeaWiFS quality flag $(\mathrm{QA}=3)$ are considered. The analysis suggests that restricting to $\mathrm{QA}=3$ does not significantly affect the way the underlying distribution of AOD is sampled, and that there is not a significant change in the quality of the SeaWiFS data through the mission. Performance is similar for the other wavelengths at which AOD is retrieved.

- Performance tends to be better over vegetated, lowlying terrain with low and moderate AOD, such as found over much of North America and Eurasia. Performance tends to be worse for low-AOD conditions near backscattering geometries (notably for scattering angles greater than $170^{\circ}$ ), where SeaWiFS overestimates AOD.

- SeaWiFS tends to underestimate AOD for opticallythick cases of absorbing aerosol, although often this underestimate remains within the expected error.

- On a regional basis, the satellites tend to produce similar seasonality to each other, and to AERONET. Differences between the satellite data are generally consistent with the known characteristics of the datasets. Unfortunately, many of the regions where large offsets exist between the satellite datasets are remote and not wellsampled by AERONET (also noted by Shi et al., 2011).

- In most regions, the typical midvisible AOD is low ( 0.3 or less), and there is little bias between any of the datasets in these conditions on aggregate. Differences in AOD tend to be largest for extreme aerosol events, in which case SeaWiFS and MISR are typically lower than AERONET or MODIS. Also notable is the fact that MODIS AOD tends to be higher than DA-MODIS, suggesting some of the elevated MODIS AOD data are too high. This is likely partially to differences between the satellite datasets in assumed aerosol microphysical properties, although factors such as cloud screening, sampling/aggregation choices, and QA differences can play roles.

In conclusion, the SeaWiFS record provides a useful complement to other satellite AOD datasets and is suitable for 
quantitative scientific analysis. It is recommended that users consider only those retrievals identified as $\mathrm{QA}=3$ (which is automatically the case with the Level 3 products), in order to extract the most reliable data for analysis, and bear in mind the results of this study depending on the geographic region of the user's desired application. Given the high quality of SeaWiFS calibration, it is hoped that through further algorithm development some assumptions related to surface reflectance and aerosol microphysical properties can be refined, improving the utility of future versions of the data.

Acknowledgements. This work was supported by a grant from the NASA MEaSUREs program, managed by Martha Maiden. MODIS data were obtained from the NASA LAADS, and MISR from the NASA Langley ASDC. The Naval Research Laboratory are thanked for the DA-MODIS data. The AERONET PIs are thanked for the creation and maintenance of the sun-photometer data records. The authors thank M. J. Garay, R. A. Kahn, O. V. Kalashnikova, R. C. Levy, S. Mattoo and L. A. Remer for helpful discussions relating to satellite aerosol datasets, and R. Gautam for insights into southern Asian aerosols. A. Lyapustin and two anonymous referees are thanked for their reviews and useful comments on the manuscript.

Edited by: O. Torres

\section{References}

Alexandrov, M. D., Marshak, A., Cairns, B., Lacis, A. A., and Carlson, B. E.: Scaling Properties of Aerosol Optical Thickness Retrieved from Ground-Based Measurements, J. Atmos. Sci., 61, 1024-1039, 2004.

Bellouin, N., Boucher, O., Haywood, J., and Shekar Reddy, M.: Global estimate of aerosol direct radiative forcing from satellite measurements, Nature, 438, 1138-1141, doi:10.1038/nature04348, 2005.

Carmichael, G. R., Ferm, M., Thongboonchoo, N., Woo, J. H., Chan, L. Y., Murano, K., Viet, P. H., Mossberg, C., Bala, R., Boonjawat, J., Upatum, P., Mohan, M., Adhikary, S. P., Shrestha, A. B., Pienaar, J. J., Brunke, E. B., Chen, T., Jie, T., Guoan, D., Peng, L. C., Dhiharto, S., Harjanto, H., Jose, A. M., Kimani, W., Kirouane, A., Lacaux, J. P., Richard, S., Barturen, O., Cerda, J. C., Athayde, A., Tavares, T., Cotrina, J. S., and Bilici, E.: Measurements of sulfur dioxide, ozone and ammonia concentrations in Asia, Africa, and South America using passive samplers, Atmos. Environ., 37, 1293-1308, doi:10.1016/S13522310(02)01009-9, 2003.

Chen, J. M. and Cihlar, J.: A hotspot function in a simple bidirectional reflectance model for satellite applications, J. Geophys. Res., 102, 25907-25913, doi:10.1029/97JD02010, 1997.

Chew, B. N., Campbell, J. R., Reid, J. S., Giles, D. M., Welton, E. J., Salinas, S. V., and Liew, S. C.: Tropical cirrus cloud contamination in sun photometer data, Atmos. Environ., 45, 6724-6731, doi:10.1016/j.atmosenv.2011.08.017, 2011.
Chylek, P., Henderson, B., and Mishchenko, M.: Aerosol radiative forcing and the accuracy of satellite aerosol optical depth retrieval, J. Geophys. Res., 108, 4764, doi:10.1029/2003JD004044, 2003.

Dubovik, O., Sinyuk, A., Lapyonok, T., Holben, B., Mischenko, M., Yang, P., Eck, T., Volten, H., Muñoz, O., Veihelmann, B., van der Zande, W. J., Leon, J.-F., Sorokin, M., and Slutsker, I.: Application of spheroid models to account for aerosol particle non-sphericity in remote sensing of desert dust, J. Geophys. Res., 111, D11208, doi:10.1029/2005JD006619, 2006.

Eck, T. F., Holben, B. N., Reid, J. S., Dubovik, O., Smirnov, A., O'Neill, N. T., Slutsker, I., and Kinne, S.: Wavelength dependence of the optical depth of biomass burning, urban, and desert dust aerosols, J. Geophys. Res., 104, 31333-31349, 1999.

Eplee Jr., R. E., Meister, G., Patt, F. S., Franz, B. A., and McClain, C. R.: Uncertainty assessment of the SeaWiFS on-orbit calibration, Proc. SPIE, 8153, 81530B, doi:10.1117/12.892340, 2011.

Gautam, R., Hsu, N. C., Kafatos, M., and Tsay, S.-C.: Influences of winter haze on fog/low cloud over the Indo-Gangetic plains, J. Geophys. Res., 112, D05207, doi:10.1029/2005JD007036, 2007.

Gautam, R., Hsu, N. C., and Lau, K. M.: Premonsoon aerosol characterization and radiative effects over the Indo-Gangetic Plains: Implications for regional climate warming, J. Geophys. Res., 115, D17208, doi:10.1029/2010JD013819, 2010.

Gautam, R., Hsu, N. C., Tsay, S. C., Lau, K. M., Holben, B., Bell, S., Smirnov, A., Li, C., Hansell, R., Ji, Q., Payra, S., Aryal, D., Kayastha, R., and Kim, K. M.: Accumulation of aerosols over the Indo-Gangetic plains and southern slopes of the Himalayas: distribution, properties and radiative effects during the 2009 pre-monsoon season, Atmos. Chem. Phys., 11, 1284112863, doi:10.5194/acp-11-12841-2011, 2011.

Gupta, P. and Christopher, S. A.: Seven year particulate matter air quality assessment from surface and satellite measurements, Atmos. Chem. Phys., 8, 3311-3324, doi:10.5194/acp-8-3311-2008, 2008.

Hasekamp, O. P. and Landgraf, J.: Retrieval of aerosol properties over land surfaces: capabilities of multi-viewing-angle intensity and polarization measurements, Appl. Optics, 46, 3332-3344, doi:10.1364/AO.46.003332, 2007.

Hoff, R. and Christopher, S.: Remote Sensing of Particulate Pollution from Space: Have We Reached the Promised Land?, J. Air Waste Manage. Assoc., 59, 645-675, doi:10.3155/10473289.59.6.645, 2009.

Holben, B. N., Eck, T. F., Slutsker, I., Tanré, D., Buis, J. P., Setzer, A., Vermote, E., Reagan, J. A., Kaufman, Y. J., Nakajima, T., Lavenu, F., Jankowiak, I., and Smirnov, A.: AERONET: A federated instrument network and data archive for aerosol characterization, Remote Sens. Environ., 66, 1-16, doi:10.1016/S00344257(98)00031-5, 1998.

Hsu, N. C., Tsay, S.-C., King, M. D., and Herman, J. R.: Aerosol properties over bright-reflecting source regions, IEEE T. Geosci. Remote, 42, 557-569, doi:10.1109/TGRS.2004.824067, 2004.

Hsu, N. C., Tsay, S.-C., King, M. D., and Herman, J. R.: Deep Blue retrievals of Asian aerosol properties during ACE-Asia, IEEE T. Geosci. Remote, 44, 3180-3195, doi:10.1109/TGRS.2006.879540, 2006. 
Hsu, N. C., Gautam, R., Sayer, A. M., Bettenhausen, C., Li, C., Jeong, M. J., Tsay, S.-C., and Holben, B. N.: Global and regional trends of aerosol optical depth over land and ocean using SeaWiFS measurements from 1997 to 2010, Atmos. Chem. Phys. Discuss., 12, 8465-8501, doi:10.5194/acpd-12-8465-2012, 2012.

Hyer, E. J., Reid, J. S., and Zhang, J.: An over-land aerosol optical depth data set for data assimilation by filtering, correction, and aggregation of MODIS Collection 5 optical depth retrievals, Atmos. Meas. Tech., 4, 379-408, doi:10.5194/amt-4-379-2011, 2011.

Ichoku, C., Chu, D. A., Mattoo, S., Kaufman, Y. J., Remer, L. A., Tanré, D., Slutsker, I., and Holben, B. N.: A spatio-temporal approach for global validation and analysis of MODIS aerosol products, Geophys. Res. Lett., 29, 8006, doi:10.1029/2001GL013206, 2002.

Kahn, R. A., Nelson, D. L., Garay, M. J., Levy, R. C., Bull, M. A., Diner, D. J., Martonchik, J. V., Paradise, S. R., Hansen, E. G., and Remer, L. A.: MISR Aerosol Product Attributes and Statistical Comparisons With MODIS, IEEE T. Geosci. Remote, 47, 40954114, doi:10.1109/TGRS.2009.2023115, 2009.

Kahn, R. A., Gaitley, B. J., Garay, M. J., Diner, D. J., Eck, T. F., Smirnov, A., and Holben, B. N.: Multiangle Imaging SpectroRadiometer global aerosol product assessment by comparison with the Aerosol Robotic Network, J. Geophys. Res., 115, D23209, doi:10.1029/2010JD014601, 2010.

Kahn, R. A., Garay, M. J., Nelson, D. L., Levy, R. C., Bull, M. A., Diner, D. J., Martonchik, J. V., Hansen, E. G., Remer, L. A., and Tanré, D.: Response to "Toward unified satellite climatology of aerosol properties: 3. MODIS versus MISR versus AERONET”, J. Quant. Spectrosc. Ra., 112, 901-909, doi:10.1016/j.jqsrt.2010.11.001, 2011.

Kalashnikova, O. V., Kahn, R., Sokolik, I. N., and Li, W.-H.: Ability of multiangle remote sensing observations to identify and distinguish mineral dust types: Optical models and retrievals of optically thick plumes, J. Geophys. Res., 110, D18S14, doi:10.1029/2004JD004550, 2005.

Knippertz, P. and Todd, M. C.: Mineral dust aerosols over the Sahara: Meteorological controls on emission and transport and implications for modeling, Rev. Geophys., 50, RG1007, doi:10.1029/2011RG000362, 2012.

Kokhanovsky, A. A. and de Leeuw, G. (Eds.): Aerosol Remote Sensing Over Land, Springer, Berlin, 2009.

Levy, R. C., Remer, L. A., Mattoo, S., Vermote, E. F., and Kaufman, Y. J.: Second-generation operational algorithm: Retrieval of aerosol properties over land from inversion of Moderate Resolution Imaging Spectroradiometer spectral reflectance, J. Geophys. Res., 112, D13211, doi:10.1029/2006JD007811, 2007.

Levy, R. C., Leptoukh, G. G., Kahn, R., Zubko, V., Gopalan, A., and Remer, L. A.: A Critical Look at Deriving Monthly Aerosol Optical Depth From Satellite Data, IEEE T. Geosci. Remote, 47, 2942-2956, doi:10.1109/TGRS.2009.2013842, 2009.

Levy, R. C., Remer, L. A., Kleidman, R. G., Mattoo, S., Ichoku, C., Kahn, R., and Eck, T. F.: Global evaluation of the Collection 5 MODIS dark-target aerosol products over land, Atmos. Chem. Phys., 10, 10399-10420, doi:10.5194/acp-10-10399-2010, 2010.

Li, Z., Zhao, X., Kahn, R., Mishchenko, M., Remer, L., Lee, K.-H., Wang, M., Laszlo, I., Nakajima, T., and Maring, H.: Uncertainties in satellite remote sensing of aerosols and impact on monitoring its long-term trend: a review and perspective, Ann. Geophys.,
27, 2755-2770, doi:10.5194/angeo-27-2755-2009, 2009.

Liu, L. and Mishchenko, M. I.: Toward unified satellite climatology of aerosol properties: Direct comparisons of advanced level 2 aerosol products, J. Quant. Spectrosc. Ra., 109, 23762385, 2008.

Martonchik, J. V., Kahn, R. A., and Diner, D. J.: Retrieval of aerosol properties over land using MISR observatons, in: Aerosol Remote Sensing Over Land, edited by: Kokhanvosky, A. A. and de Leeuw, G., Springer, Berlin, 2009.

McClain, C. R., Feldman, G. C., and Hooker, S. B.: An overview of the SeaWiFS project and strategies for producing a climate research quality global ocean bio-optical time series, Deep-Sea Res., 51, 5-42, doi:10.1016/j.dsr2.2003.11.001, 2004.

Meskhidze, N., Remer, L. A., Platnick, S., Negrón Juárez, R., Lichtenberger, A. M., and Aiyyer, A. R.: Exploring the differences in cloud properties observed by the Terra and Aqua MODIS Sensors, Atmos. Chem. Phys., 9, 3461-3475, doi:10.5194/acp9-3461-2009, 2009.

Mishchenko, M. I., Geogdzhajev, I., Liu, L., Lacis, A. A., Cairns, B., and Travis, L. D.: Toward unified satellite climatology of aerosol properties: What do fully compatible MODIS and MISR aerosol pixels tell us?, J. Quant. Spectrosc. Ra., 110, 402-408, 2009.

Mishchenko, M. I., Liu, L., Travis, L. D., Lacis, A. A., and Cairns, B.: Toward unified satellite climatology of aerosol properties: 3. MODIS versus MISR versus AERONET, J. Quant. Spectrosc. Ra., 111, 540-552, 2010.

O’Neill, N. T., Ignatov, A., Holben, B. N., and Eck, T. F.: The lognormal distribution as a reference for reporting aerosol optical depth statistics; Empirical tests using multi-year, multi-site AERONET Sunphotometer data, Geophys. Res. Lett., 27, 3333 3336, doi:10.1029/2000GL011581, 2000.

Prospero, J. M., Ginoux, P., Torres, O., Nicholson, S. E., and Gill, T. E.: Environmental characterization of global sources of atmospheric soil dust identified with the NIMBUS 7 Total Ozone Mapping Spectrometer (TOMS) absorbing aerosol product, Rev. Geophys., 40, 1002, doi:10.1029/2000RG000095, 2002.

Sayer, A. M., Thomas, G. E., Palmer, P. I., and Grainger, R. G.: Some implications of sampling choices on comparisons between satellite and model aerosol optical depth fields, Atmos. Chem. Phys., 10, 10705-10716, doi:10.5194/acp-10-10705-2010, 2010.

Sayer, A. M., Hsu, N. C., Bettenhausen, C., Ahmad, Z., Holben, B. N., Smirnov, A., Thomas, G. E., and Zhang, J.: SeaWiFS Ocean Aerosol Retrieval (SOAR): Algorithm, validation, and comparison with other datasets, J. Geophys. Res, 117, D03206, doi:10.1029/2011JD016599, 2012.

See, S. W., Balasubramanian, R., and Wang, W.: A study of the physical, chemical, and optical properties of ambient aerosol particles in Southeast Asia during hazy and nonhazy days, J. Geophys. Res., 111, D10S08, doi:10.1029/2005JD006180, 2006.

Shi, Y., Zhang, J., Reid, J. S., Hyer, E. J., Eck, T. F., Holben, B. N., and Kahn, R. A.: A critical examination of spatial biases between MODIS and MISR aerosol products - application for potential AERONET deployment, Atmos. Meas. Tech., 4, 2823 2836, doi:10.5194/amt-4-2823-2011, 2011.

Shinozuka, Y. and Redemann, J.: Horizontal variability of aerosol optical depth observed during the ARCTAS airborne experiment, Atmos. Chem. Phys., 11, 8489-8495, doi:10.5194/acp-11-84892011, 2011. 
Smirnov, A., Holben, B. N., Eck, T. F., Dubovik, O., and Slutsker, I.: Cloud-screening and quality control algorithms for the AERONET database, Remote Sens. Environ., 73, 337-349, 2000.

Smirnov, A., Holben, B. N., Eck, T. F., Slutsker, I., Chatenet, B., and Pinker, R. T.: Diurnal variability of aerosol optical depth observed at AERONET (Aerosol Robotic Network) sites, Geophys. Res. Lett., 29, 2115, doi:10.1029/2002GL016305, 2002.

Swap, R., Garstang, M., Macko, S. A., Tyson, P. D., Maenhaut, W., Artaxo, P., Kållberg, P., and Talbot, R.: The long-range transport of southern African aerosols to the tropical South Atlantic, J. Geophys. Res., 101, 23777-23791, doi:10.1029/95JD01049, 1996.

Wagner, F. and Silva, A. M.: Some considerations about Ångström exponent distributions, Atmos. Chem. Phys., 8, 481-489, doi:10.5194/acp-8-481-2008, 2008.

Yoon, J., von Hoyningen-Huene, W., Vountas, M., and Burrows, J. P.: Analysis of linear long-term trend of aerosol optical thickness derived from SeaWiFS using BAER over Europe and South China, Atmos. Chem. Phys., 11, 12149-12167, doi:10.5194/acp11-12149-2011, 2011.
Zhang, J. and Reid, J. S.: A decadal regional and global trend analysis of the aerosol optical depth using a data-assimilation grade over-water MODIS and Level 2 MISR aerosol products, Atmos. Chem. Phys., 10, 10949-10963, doi:10.5194/acp-1010949-2010, 2010.

Zhang, J., Reid, J. S., Westphal, D. L., Baker, N. L., and Hyer, E. J.: A System for Operational Aerosol Optical Depth Data Assimilation over Global Oceans, J. Geophys. Res., 113, D10208, doi:10.1029/2007JD009065, 2008.

Zhang, J., Campbell, J. R., Reid, J. S., Westphal, D. L., Baker, N. L., Campbell, W. F., and Hyer, E. J.: Evaluating the Impact of Assimilating CALIOP-derived Aerosol Extinction Profiles on a Global Mass Transport Model, Geophys. Res. Lett., 38, L14801, doi:10.1029/2011GL047737, 2011. 